\title{
RELEVANSI KAJIAN HUKUM ADAT: KASUS PERKAWINAN ANAK DARI MASA KE MASA
}

\author{
Sita Thamar van Bemmelen* dan Mies Grijns**
}

\author{
Peneliti independen \\ Van Vollenhoven Institute for Law, Governance and Society, Leiden Law School
}

\begin{abstract}
Although the prevalence of child marriage in Indonesia is still high, adat law studies on child marriage have not received as much attention as land-related studies. This research concerning a century of political debate on child marriage proves that child marriage can only be understood if examined from the perspective of the dynamic relationship between national law, religious law, and adat law. A comparison between the results of an antrophological case study on West Java (Sundanese and Islam) and a historical case study on North Sumatra (Toba Batak and Christian) shows that the legal culture of the community and the role of religious leaders are important determinants of the acceptance or rejection of child marriage.
\end{abstract} Keywords: customary child marriage, child rights, family law diversity, Sunda, Toba Batak.

\section{Intisari}

Meskipun prevalensi perkawinan anak di Indonesia masih tinggi, studi hukum adat terhadap perkawinan anak belum mendapat perhatian sebesar studi terkait tanah. Penelitian tentang satu abad debat politik tentang perkawinan anak ini membuktikan bahwa perkawinan anak hanya dapat dipahami bila diteliti dari sudut dinamika antara hukum negara, hukum agama dan hukum adat. Perbandingan studi kasus penelitian antropologi di Jawa Barat (suku Sunda, Islam) dan studi kasus sejarah di Sumatra Utara (suku Batak Toba, Kristen) menunjukkan bahwa budaya hukum masyarakat dan peran pemimpin agama adalah faktor penting penentu penerimaan atau penolakaan perkawinan anak.

Kata Kunci: adat perkawinan anak, hak anak, keberagamaan hukum keluarga, Sunda, Batak Toba.

\section{Pokok Muatan}

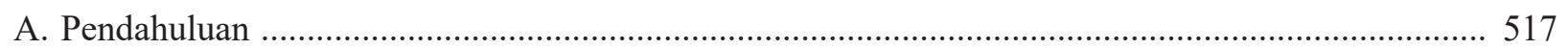

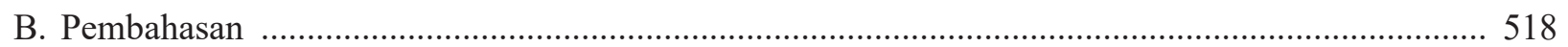

1. Relevansi Kajian Hukum Adat Perkawinan ................................................................................ 518

2. Perkawinan Anak antara Hukum Adat, Hukum Agama, dan Hukum Negara ............................. 520

3. Perkawinan Anak dan Intervensi Pemerintah Kolonial dan Indonesia ....................................... 522

4. Perkawinan Anak yang Bertahan di Pedesaan Jawa Barat, Kabupaten Sukabumi ..................... 513

5. Strategi Menurunkan Umur Perkawinan: Kasus Batak Toba (Tapanuli Utara) ............................ 535

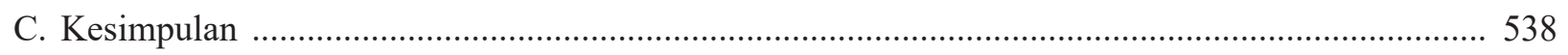

Alamat korespondensi: bemmelen.sita@gmail.com.

Alamat korespondensi: m.grijns@law.leidenuniv.nl. 


\section{A. Pendahuluan}

Saat ini, masyarakat luas, sebagian komunitas peneliti dan praktisi hukum cenderung memandang hukum adat sebagai warisan masa lampau saja. Hukum adat pernah tumbuh dan berkembang di masyarakat tradisional. Sistem hukum adat bersifat lokal, hingga kemudian keberadaannya dirongrong pemerintah kolonial dan semakin pudar setelah masa kemerdekaan.

Wilayah di mana hukum adat masih dianggap relevan untuk diteliti lebih banyak berkaitan dengan tanah. ${ }^{1}$ Anggapan ini dapat dipahami mengingat saat ini terjadi ribuan konflik tanah di Indonesia dan meliputi jutaan hektar tanah di Indonesia. Akan tetapi, pada wilayah yang lain, terutama yang terkait dengan urusan perkawinan, para akademisi tidak memberi perhatian kepada hukum adat sebesar pada hukum adat terkait tanah. Melalui artikel ini kami ingin menunjukkan bahwa kajian hukum adat tentang keluarga sangat bermanfaat.

Kami memusatkan perhatian pada aspek perkawinan yang merupakan topik penelitian kami, yaitu perkawinan anak. Topik ini tidak kunjung mendapat perhatian sejak Pemerintah Republik Indonesia menetapkan Undang-Undang Nomor 1 Tahun 1974 tentang Perkawinan (selanjutnya UU Perkawinan). Undang-undang ini menetapkan bahwa usia perkawinan minimal 16 tahun untuk perempuan, dan 19 tahun untuk laki-laki. Sebagai konsekuensinya, debat tentang usia perkawinan anak yang sudah menjadi isu publik semenjak akhir abad kesembilanbelas berakhir disini.

Pemerintah dan masyarakat luas kurang memperhatikan sejauh mana masyarakat mengindahkan batas umur tersebut karena beranggapan bahwa instrumen hukum yang mengatur batas usia tersebut telah tersedia.
Padahal, data statistik dari sensus nasional yang dilaksanakan beberapa kali sejak Undang-Undang tersebut diberlakukan, menunjukkan betapa besar jumlah anak yang masih menikah di bawah batas umur minimum untuk menikah. Beberapa kali publik memang digoncangkan oleh berita tentang anak perempuan yang masih sangat belia yang dijodohkan orang tuanya. Contoh yang paling dikenal masyarakat luas adalah perkawinan Lutfiana Ulfa yang waktu itu berumur 12 tahun, dengan Syekh Puji (usianya 43 tahun) pada tahun 2008. Akan tetapi, pada masa itu perkawinan anak belum dianggap sebagai masalah makro.

Isu perkawinan anak baru menjadi perbincangan hangat dan serius setelah perkawinan anak diangkat di tingkat internasional oleh The Elders sebagai kondisi yang merugikan bukan hanya anak perempuan saja, tetapi juga negara yang sedang berkembang. ${ }^{2}$ Memang tidak dapat dipungkiri, bahwa keberlangsungan perkawinan anak merupakan hambatan signifikan untuk mencapai tujuan pembangunan seperti pemberantasan kemiskinan, pencapaian MDGs (Millenium Development Goals 2000-2015) kemarin dan kemudian SDGs (Sustainable Development Goals 2016-2030). Para aktivis perempuan dan anak telah mulai menyuarakan pentingnya intervensi untuk menekan prevalensi perkawinan anak, termasuk intervensi hukum berupa peningkatan usia minimum untuk menikah menjadi 18 tahun, untuk anak perempuan maupun anak laki-laki. ${ }^{3}$

Pada bagian pertama artikel ini kami menjelaskan alasannya dan juga mengapa hukum adat terkait perkawinan sebenarnya tidak kalah penting dibandingkan hukum adat terkait tanah. Sejatinya, tidaklah cukup untuk menghapus perkawinan anak dengan revisi UU Perkawinan

1 Inilah isu utama yang dibahas waktu konferensi ‘Adat law 100 years on: towards a new interpretation?' yang diadakan pada tanggal 22-24 Mei 2017, National Museum of Ethnology, Leiden, the Netherlands. Untuk rangkuman makalah lihat laporan konferensi (Vel dan van der Muur 2017).

2 Girls Not Brides, adalah gerakan global yang saat ini berkembang di 95 negara dan didorong oleh 1000 LSM. Girls Not Brides adalah inisitatif sejumlah tokoh politik termasyur dari berbagai belahan dunia yang disebut The Elders, pada tahun 2011. The Elders telah menemukan bahwa perkawinan anak berdampak sangat buruk di seluruh dunia dan mereka memutuskan untuk mengangkatnya sebagai isu utama dalam upaya memajukan kesetaraan dan keadilan gender. Lihat: https://theelders.org/dan https://www.girlsnotbrides.org/about-girls-not-brides/\#history.

3 Nurul F. Ramadhani dan Ati Nurbaiti, "Avoiding child marriage "mandatory", http://www.thejakartapost.com/news/2017/04/28/avoidingchild-marriage-mandatory.html, diakses tanggal 29 April 2017. 
atau dengan mengeluarkan Peraturan Presiden. Dalam upaya untuk mengurangi perkawinan anak, pengaruh adat, hukum adat, dan hukum agama masih harus diperhitungkan karena menyumbang pengaruh besar bagi perkawinan anak. Letak pengaruh unsur adat, dan hukum adat, agama serta hukum nasional itu dijelaskan di bagian kedua dari tulisan ini.

Pada bagian ketiga kami membahas intervensi untuk memberantas perkawinan anak melalui kebijakan di bidang hukum yang sudah diupayakan semenjak masa kolonial sampai sekarang. ${ }^{4}$ Kami menemukan bahwa intervensi negara pada akhirnya selalu ditolak.

Di bagian keempat kami turun ke lapangan untuk menelusuri mengapa intervensi negara melalui batas umur 16 tahun untuk perempuan yang ditetapkan dalam UU Perkawinan tidak dipatuhi oleh masyarakat. Temuan-temuan kami tersebut berdasarkan penelitian di Jawa Barat, salah satu daerah di mana prevalensi perkawinan anak masih terus tinggi. Sebagai pembanding, pada bagian kelima tulisan, kami menampilkan keadaan di satu propinsi di mana prevalensi rendah, yaitu Propinsi Sumatera Utara. Di beberapa kabupaten propinsi ini, perkawinan anak pada zaman dulu juga merupakan kebiasaan. Akan tetapi telah terjadi perubahan amat signifikan. Faktor apa saja yang mendorong perubahan itu dijelaskan.

Temuan kami menghasilkan masukan mengenai faktor yang menentukan tinggi-rendahnya prevalensi perkawinan anak yang dipaparkan di bagian kesimpulan. Temuan itu dapat bermanfaat untuk perencanaan intervensi hukum komprehensif untuk menghapus perkawinan anak.

\section{B. Pembahasan}

1. Relevansi Kajian Hukum Adat Perkawinan Sebagaimana sudah dipaparkan di atas, kami menemukan bahwa hukum adat terkait perkawinan tidak mendapat perhatian sebanding dengan hukum adat terkait tanah. Hal itu terjadi karena penjelasan sebagai berikut. Pertama, bila terjadi konflik tentang tanah adat, yang menuntut haknya adalah sebuah komunitas adat, sedangkan bila ada pertentangan antara substansi hukum adat dan UU perkawinan, anggota keluarga lebih banyak menjadi pihak yang berkepentingan. Belum tentu individu yang dirugikan, bila hukum adat bersifat diskriminatif, bersedia atau berani menuntut haknya. Hal ini menyebabkan masalah yang dihadapinya jarang sekali muncul ke permukaan. Kedua, hukum adat perkawinan termasuk hukum perdata. Perubahannya sulit untuk disepakati, karena masuk ke ruang privat. Debat mengenai peraturan hukum negara terkait perkawinan dari masa kolonial sampai sekarang membuktikan hal tersebut.

Ketiga, berkaitan juga dengan alasan kedua, hukum adat di banyak daerah dipengaruhi oleh hukum Islam. Konsekuensinya, aspek hukum adatnya tenggelam di bawah bayang-bayang hukum Islam. Keempat, bersama dengan adat istiadat perkawinan secara umum, kebijakan Orde Baru mengemas hukum adat sebagai bagian dari budaya yang dimiliki kelompok etnis. Dampaknya, di dunia akademis hukum adat perkawinan dianggap lebih cocok dikaji oleh para antropolog ketimbang para peneliti hukum. Kelima, tekanan pada aspek magis religius hukum adat mungkin merupakan alasan lain mengapa pengaruh hukum adat terkait perkawinan kurang diminati peneliti sekarang. Padahal, dalam kenyataan budaya hukum masyarakat yang berakar dalam hukum adat lama masih berpengaruh walaupun dengan intensitas yang berbeda antar daerah. Lagipula, tokoh adat di beberapa komunitas adat masih berfungsi dalam kasus tertentu, termasuk yang menyangkut perkawinan anak sebagaimana dijelaskan di bawah.

Keenam, tinggal sedikit pakar hukum adat yang masih menguasai Bahasa Belanda. Akibatnya,

4 Bagian 3 merupakan rangkuman Sita van Bemmelen \& Mies Grijns, "Perdebatan Tentang Perkawinan Anak, Mulai dari Zaman Kolonial Hingga ke Kurun Jawa Masa Kini: Adat, Agama dan Negara", dalam Mies Grijns, et al., 2018, Menikah Muda di Indonesia: Suara, Hukum dan Praktik, Yayasan Pustaka Obor Indonesia, Jakarta, hlm. 324-365. Referensi pada artikel di koran berbahasa Belanda yang terbit di masa penjajahan dapat dilihat di artikel tersebut. 
bahan pustaka yang dihasilkan pakar hukum adat Belanda dan Indonesia pada zaman penjajahan tidak dapat dipakai. ${ }^{5}$ Ketujuh, para pengambil keputusan politik tingkat nasional yang terdidik dan urban, jarang berhadapan dengan praktek hukum adat di daerah asal mereka. Dampaknya, apabila ada ketidakselarasan antara hukum adat, hukum agama, dan hukum nasional, itu tidak dianggap sebagai suatu masalah yang perlu diatur. Atau mereka menganggap masalah itu terlalu pelik untuk ditangani karena sulit sekali menemukan konsensus politik. Terakhir dan tidak kalah penting, hukum adat masih mempunyai konotasi negatif. Hukum adat dipandang sebagai warisan kebijakan kolonial yang melayani kepentingan ekonomi dan politik penjajah. ${ }^{6}$

Meskipun demikian, tidak dapat dipungkiri bahwa hukum adat masih menjadi bagian kehidupan masyarakat di daerah. Kondisi tersebut menimbulkan gejala keberagaman hukum (legal pluralism) yang sangat kompleks sebagai akibat interaksi hukum adat dengan tatanan hukum lainnya. Dengan demikian, timbul pertanyaan: kajian hukum adat seperti apakah yang masih relevan? Sudah jelas, meskipun pernah populer pada masa kolonial, kajian berbentuk monografi hukum adat saat ini kurang relevan. Pada akhir abad kesembilanbelas kajian seperti itu diperlukan mengingat pemerintah kolonial Belanda berhadapan dengan dilema saat berupaya mengintroduksi hukum sipil Belanda di wilayah yang menjadi bagian dari pemerintahan kolonialnya.

Pada saat itu, masih banyak daerah yang menerapkan hukum adat dan memiliki penegak hukum adat seperti kepala suku, menak, penghulu, pendeta atau orang dengan kedudukan tradisional lain. Keuntungan mempertahankan sistem hukum adat dan pengadilan adat waktu itu jelas: kepastian hukum terjamin karena hukum adat berakar dalam norma dan rasa keadilan dan kepatutan masyarakat setempat. ${ }^{7} \quad$ Keuntungan lain adalah dengan mempertahankan hukum adat maka ketentraman dan ketertiban (rust en orde) lebih terjamin. Pendekatan Adat Law School (Adatrechtsschool) yang diprakarsai oleh Prof. Cornelis van Vollenhoven dan diikuti oleh murid-muridnya yang menghasilkan sejumlah monografi dan karya tulis lain, menyokong kebijakan tersebut. ${ }^{8}$ Setelah pengesahan UU Perkawinan kajian hukum adat masih dianggap perlu, khususnya untuk menentukan status hukum adat dalam konstelasi hukum yang baru. $^{9}$

Keadaan sekarang sudah sangat berbeda dibandingkan dengan kondisi pada masa penjajahan. Pada bidang hukum keluarga sudah ada instrumen hukum negara yang mengaturnya seperti UU Perkawinan dan Kompilasi Hukum Islam tahun 1991. Keadaan ini mendorong adanya ketidakselarasan hukum adat dengan hukum nasional dan hukum Islam. Situasi ini cukup mudah ditelusuri pada hukum adat kelompok etnis yang berakar dalam sistem kekerabatan yang dipertahankan masing-masing suku. Beberapa contoh cukup untuk membuktikan itu. Kelompok etnis yang menganut sistem kekerabatan patrilineal, misalnya masyarakat Bali, Toba, dan sejumlah suku di NTT dan Papua, tidak memberi hak waris pada perempuan, juga tidak hak asuh anak bila terjadi perceraian, sementara UU Perkawinan menetapkan hak-hak tersebut.

5 Adriaan Bedner, "Some Notes on The Future of Indonesian Legal Education", Makalah, International Conference on Southeast Asia Legal Education: Preparing Lawyers for Tomorrow's Society and Profession, Fakultas Hukum Universitas Airlangga, Surabaya, 2 Oktober 2013, hlm. 4.

6 Bedner yang menawarkan pandangan yang lebih bernuansa, lihat Adriaan Bedner, Ibid., hlm. 3.

7 Mempertahankan hukum adat lahir merupakan kebijakan pragmatis: kesulitan pemerintah mengatasi jumlah perkara yang dibawa ke pengadilan oleh masyarakat di daerah yang belakangan masuk negara kolonial disertai kekurangan hakim berpendidikan formal dan kekurangan anggaran, Sita van Bemmelen, 2018, Christianity, Colonization, and Gender Relations in North Sumatra. A Patrilineal Society in Flux, Brill, Leiden/Boston, hlm. 247-366.

8 Harko Sonius, "Introduction", dalam Johan Frederik Holleman, 1981, Van Vollenhoven on Indonesian Adat Law, Martinus Nijhoff, The Hague, hlm. LVIII.

9 Soerjono Soekanto, 1982, Kedudukan dan Peranan Hukum Adat di Indonesia, Penerbit Kurnia Esa, Jakarta, lihat juga Surojo Wignjodipuro, 1982, Kedudukan serta Perekembangan Hukum Data Setelah Kemerdekaan, PT Gunung Agung, Jakarta. 
Keadaan di suku Minang yang menganut sistem kekerabatan matrilineal lebih kompleks. Hukum adat Minangkabau memberi hak atas harta pada kaum perempuan saja. Akan tetapi hukum Islam yang mereka anut memakai patokan sepikulsegendongan, di mana dua pertiga bagian waris untuk lelaki dan sepertiga bagian waris untuk perempuan, sementara hukum nasional menetapkan hak waris laki-laki dan perempuan sama. Suku Jawa, Sunda, dan Madura menganut sistem bilineal, sehingga hukum adat mereka mengenai waris sama dengan hukum nasional, yaitu memberikan hak yang sama pada lelaki dan perempuan untuk mewaris. Akan tetapi, aturan itu berbeda dengan hukum agama Islam yang dianut suku tersebut. ${ }^{10}$

Berdasarkan kehadiran keberagaman hukum tersebut dapat diperkirakan bahwa pihak yang dirugikan apabila hukum perdata nasional yang paling adil gender diterapkan, akan berupaya keras untuk mempertahankan hak prerogatifnya. Strategi pertamanya adalah menjaga supaya pihak yang dirugikan tidak sampai membawa perkara ke pengadilan. Itu menyangkut terutama kaum perempuan yang seringkali posisi tawarmenawarnya dalam keluarga bersifat lemah - apalagi bila perempuan itu tergantung secara ekonomi pada suami dan kerabat laki-laki. Perempuan biasanya akan mengalah atau dipaksa mengalah. Ada juga sedikit yang memperjuangkan haknya melalui peraturan yang paling menguntungkan bagi dia. ${ }^{11}$ Namun, apabila dia menuntut haknya menurut hukum nasional, belum tentu diamendapatkeputusan hakim yang sesuai, karena hakim menghadapi dilema berikut: bila keputusannya mengindahkan hukum nasional belum tentu keputusannya dapat dieksekusi karena bertentangan dengan budaya hukum setempat sehingga pihak keluarga yang merasa dirugikan akan menentangnya, bahkan mengambil secara sewenang-wenang apa yang dianggap haknya menurut hukum adat. ${ }^{12}$ Dengan kata lain, para hakim menghadapi dilema bahwa mereka harus memilih keputusan yang menjamin keadilan (justice) atau yang menjamin kepastian hukum, yaitu keputusannya menyelesaikan perkara dengan hasil yang bisa dijamin (legal certainty). Hal tersebut merupakan dilema klasik.

Masih ada serangkaian persoalan lain yang merugikan perempuan seperti misalnya, apabila perkawinannya tidak sah menurut hukum negara. Termasuk perkawinan yang tidak sah adalah perkawinan di bawah tangan, nikah siri, kawin kontrak. Dalam perceraian pun, tidak sahnya perkawinan menurut hukum negara akan berdampak pada tidak dapat dikukuhkannya perceraian melalui keputusan pengadilan. Perceraian diselesaikan tanpa formalitas apapun atau hanya berdasarkan adat saja.

Semoga penjelasan ini cukup meyakinkan sebagai dasar argumen kami bahwa kajian hukum adat terkait perkawinan masih sangat relevan, baik dari segi substansinya, maupun penerapannya oleh tokoh adat dan sebagai sumber budaya hukum masyarakat. Penjelasan ini juga menyampaikan pesan bahwa hukum adat terkait perkawinan harus dikaji dari sudut interaksinya dengan hukum agama dan hukum nasional. Perlu diingat juga, bahwa persoalan-persoalan disebut di atas mempengaruhi kehidupan sebagian besar penduduk Indonesia. Bahkan menyangkut lebih banyak orang daripada perkara tanah adat.

\section{Perkawinan Anak antara Hukum Adat, Hukum Agama, dan Hukum Negara}

Secara kasat mata, perkawinan anak merupakan kebiasaan sosial saja. Tidak ada aturan adat ataupun hukum lain yang mengatur bahwa anak harus menikah, apalagi harus menikah pada umur

10 Khususnya status hukum perempuan yang sudah menikah menurut masing sistem kekerabatan dikupas oleh Boomgaard (1926) untuk domisili pasangan (residence), hak atas harta, hak untuk minta cerai, haknya janda untuk menikah lagi, hak atas warisan, dan hak perwalian.

11 Sulistyowati Irianto, 2003, Perempuan di Antara Berbagai Pilihan Hukum, Yayasan Pustaka Obor Indonesia, Jakarta, dan lihat jugaSulistyowati Irianto, “Adat Law in Legal Pluralism Perspective: Inheritance Dispute Case and Gender Justice", Makalah, Conference Adat Law 100 Years On: Towards a New Interpretation? Van Vollenhoven Institute, Leiden University, Leiden, 22-24 Mei 2017.

12 Ada kasus di Bali dimana hakim memberikan hak asuh anak pada pihak istri, tetapi anak itu kemudian diculik oleh pihak keluarga suami. Informasi LBH-APIK Bali (sumber: rekan Sita Thamar van Bemmelen di LBH APIK) 
yang masih belia. Namun, seperti halnya dengan perkawinan secara umum, perkawinan anak selalu punya berbagai akibat hukum. Pertama, perkawinan sesuai dengan aturan adat, agama, dan hukum negara melegitimasi hubungan antara seorang lakilaki dan perempuan sebagai suami-istri di mata negara, komunitas adat, dan umat beragama ${ }^{13}$. Kedua, perkawinan tidak hanya menyatukan dua insan manusia dalam sebuah perkawinan tetapi juga bisa mengatur hubungan antar dua keluarga, yang terekspresi dalam tutur-menutur antara mereka. Ketiga, perkawinan itu seringkali disertai perjanjian yang mungkin tertulis tetapi tidak berupa kontrak formal: misalnya menyangkut harta kekayaan bride price (belis, sinamot, mahar dan lain sebagainya). ${ }^{14}$ Menurut hukum adat lama harta itu harus dikembalikan kepada pihak pemberi apabila pasangan bercerai di kemudian hari. Keempat, sebuah komunitas bisa menjatuhkan sanksi adat apabila perjanjian nikah dibatalkan sepihak. Kelima, masih ada suku yang menetapkan aturan bahwa pasangan yang perkawinannya belum dilangsungkan menurut adat akan memperoleh sanksi tidak boleh berbicara di rapat adat keluarga besar, dan tidak boleh mengadakan upacara adat perkawinan dan kematian untuk anggota keluarga mereka. Keenam, perkawinan juga mengatur status hukum anak yang lahir dari pernikahan: anak itu sah atau tidak, baik menurut hukum formal, hukum adat maupun hukum agama? Status hukum seorang anak yang sah tidak hanya menyangkut identitas hukumnya menurut hukum negara, yang dibuktikan melalui akte kelahiran. Bagi banyak orang, status hukum anak di mata hukum agama dan adat tidak kalah penting. ${ }^{15}$

Pembahasan yang lebih penting dalam rangka kajian tentang perkawinan anak adalah terkait dengan status hukum seorang anak yang lahir di luar nikah. Menurut Pasal 43 (1) UU Perkawinan anak yang dilahirkan di luar perkawinan hanya mempunyai hubungan perdata dengan ibunya. Legal identity anak itu tetap dapat diperoleh, namun di akte kelahirannya hanya nama ibu kandungnya tercantum. ${ }^{16}$ Sejak 2012 ada terobosan terkait hubungan anak itu dengan bapak kandungnya: Mahkamah Konstitusi telah mengabulkan uji materi pasal tentang anak di luar pernikahan dalam UU Perkawinanbahwaanakyanglahirdi luarperkawinan tetap mempunyai hubungan keperdataan dengan ayah biologisnya. ${ }^{17}$ Beberapa agama mengatur hubungan anak anak luar kawin dengan ketentuan yang berbeda-beda. Menurut hukum Islam, anak yang lahir di luar perkawinan yang sah adalah 'anak haram' atau 'anak zina'. Status ini menyebabkan hubungan keperdataan dengan bapak kandungnya terputus. Akibatnya, sang anak tidak dapat diakui sebagai ahli waris bapak kandungnya tersebut. ${ }^{18}$ Gereja tidak mengizinkan pembaptisan anak yang lahir di luar nikah. Di masyarakat Hindu Bali sanksi agama yang dijatuhkan pada pihak perempuan

13 Urutan adat, agama dan negara tidak sama di semua suku. Misalnya di daerah Batak dan Sumba menikah dulu di gereja, baru menurut adat karena upacara adat mahal (van Bemmelen, 2018: 513-4), lihat juga Jacqueline Vel, 1994, The Uma-Economy: Indigenous Economics and Development Work in Lawonda, Sumba (Eastern-Indonesia), Disertasi, Wageningen University, Wageningen. Tetapi di daerah Dayak Kebahan pernikahan di gereja baru dibolehkan kalau upacara adat sudah beres, lihat Alfonso Munte, 2017, "Pernikahan Anak: Studi Kasus antara Nikah Adat dan Nikah Rehap (Gereja), Dayak Kebahan, Kayan Hulu, Kalimantan Barat", Makalah, Workshop on Child Marriage in Indonesia: Research Sharing and Academic Writing, Universitas Indonessia, Jakarta, 27 April 2017.

14 Dalam hal ini perlu dibedakan antara pemberian harta dari pihak perempuan kepada pihak laki-laki yang disebut dalam bahasa Inggris dowry yang banyak dipraktekkan di masyarakat di India, dan pemberian harta dari pihak laki-laki kepada pihak perempuan yang disebut bride price. Dalam Bahasa Indonesia istilah untuk dowry dan brideprice sama, yaitu mas kawin. Nilai ekonomis bride price bisa puluhan juta seperti misalnya belis di NTT dan di masyarakat Bugis, Sulawesi Selatan. Sementara mahar (Arab: mahr) yang wajib diberikan saat akad nikah di Jawa biasanya nilai ekonomisnya rendah. Penerima mahar adalah perempuan sendiri, yang menjadi pemiliknya.

15 Menurut agama Kristen hanya anak yang lahir dalam perkawinan yang diberkati gereja, bisa diterima sebagai anggota jemaat melalui pembaptisan. Umat Islam mengenal ritual sunatan, tetapi ritual itu tidak berfungsi sebagai pengakuan status hukum anak, karena anak itu sudah diterima sebagai anak sah apabila lahir dalam perkawinan yang dilangsungkan secara Islam.

16 Sehingga anak itu diledeki kalau ketahuan statusnya.

17 Yuniman Farid, "MK Beri Status Hukum Anak Luar Nikah”, www.dw.com/id/mk-beri-status-hukum-anak-luar-nikah/a-15747844, diakses tanggal 5 Agustus 2018 .

18 Editor Almanhaj, "Hamil di Luar Nikah dan Masalah Nasab Anak Zina”, https://almanhaj.or.id/2099-hamil-di-luar-nikah-dan-masalahnasab-anak-zina.html, diakses tanggal 5 Agustus 2018; Editor Almanhaj, "Status Anak Zina”, https://almanhaj.or.id/3354-status-anak-zina. html, diakses tanggal 5 Agustus 2018. 
berupa pelaksanaan upacara agama yang dananya besar untuk menyucikan kembali wilayah desa yang dianggap dinodai dengan adanya anak yang lahir di luar nikah. Di daerah tertentu sanksi adat masih ada. Bentuknya berupa kewajiban keluarga perempuan untuk membayar denda atau keluarga diusir dari desa. ${ }^{19}$

Mengingat beratnya sanksi agama dan adat, tidak perlu heran bahwa orang tua remaja perempuan yang hamil di luar nikah berupaya sekeras-kerasnya untuk mengurus perkawinan anak perempuannya sebelum dia melahirkan. ${ }^{20}$ Walaupun belum ada data mengenai persentase perkawinan anak saat ini yang termasuk kategori 'married by accident' (MBA), yang jelas jumlahnya cukup banyak. Mungkin bahkan melebihi perkawinan anak melalui penjodohan orang tua. MBA adalah fenomena yang relatif baru. Orang tua sekarang tidak mampu mengontrol perilaku anak-anak mereka seperti dulu saat anak-anak masih jarang sekolah di atas tingkat Sekolah Dasar (SD). Sekarang, mobilitas remaja jauh lebih tinggi dan mereka seringkali mulai pacaran saat Sekolah Menengah Pertama atau Atas (SMP dan SMA). Belakangan remaja juga memiliki akses yang tak terbatas atas internet melalui HP. ${ }^{21}$

Bila terjadi kehamilan di luar nikah, maka baik remaja perempuan itu maupun pasangannya merasa tidak berdaya dan cenderung tunduk pada keputusan orang tuanya untuk segera menikah. Biasanya si perempuan menikah dengan pacarnya yang merupakan ayah biologis dari si bayi. Tetapi bila si pria atau keluarganya menolak, si perempuan bisa dijodohkan dengan pria lain yang ditentukan oleh orang tuanya. ${ }^{22}$ Dalam kasus seperti itu, keinginan sendiri remaja perempuan yang belum cukup usia (di bawah 16 tahun sesuai UU Perkawinan) dikesampingkan. Bagaimana terobosan hukum yang terbaik menurut kami akan dipaparkan di bagian 6 .

\section{Perkawinan Anak dan Intervensi Pemerin- tah Kolonial dan Indonesia}

Pada abad kesembilanbelas pemerintah kolonial Belanda mengetahui bahwa perkawinan anak merupakan kebiasaan umum di seluruh Nusantara. Akan tetapi pada saat itu pemerintah merasa bahwa tidak perlu mencampuri urusan masyarakat pribumi. ${ }^{23}$ Baru awal abad keduapuluh, dalam rangka politik etis yang diumumkan Ratu Belanda Wilhelmina pada tahun 1901, pemerintah mulai menganggap perkawinan anak sebagai sebuah masalah yang perlu diberantas, terutama karena menghambat peningkatan ekonomi dan kesejahteraan masyakarat di pulau Jawa dan Madura. Walaupun dalam rangka penelitian tentang kesejahteraan yang dinilai kurang memadai sejumlah bupati (regenten) sependapat dengan pemerintah dan juga sejumlah tokoh perempuan Jawa dan Sunda terdidik dari kalangan bangsawan, tidak ada di antara mereka yang menyarankan untuk mengeluarkan peraturan hukum yang mengatur umur perkawinan (Onderzoek 1914: 6-9; 1*-38*). Alasannya hanya diungkapkan oleh Siti Soendari, wartawati terkenal dan pengurus majalah Wanito Sworo: intervensi seperti itu akan bertentangan dengan agama (yang dimaksud agama Islam). Seperti yang lain Siti Soendari berharap bahwa perkawinan anak (perempuan) akan berkurang secara alamiah jika lebih banyak anak perempuan disekolahkan. Pada kurun waktu itu akses pada pendidikan kemudian dibuka lebih lebar karena

19 Penelitian tentang kehamilan yang tidak dikehendaki di 8 provinsi di pulau Sumatera, menemukan bahwa sanksi adat masih diberlakukan, termasuk di daerah yang penduduknya beragama Islam seperti Aceh, Sumatera Barat, Jambi, Lampung, lihat Mampu, 2015, Kehamilan sebuah Anugerah? Kompilasi Laporan Penelitian Kehamilan Tidak Diinginkan/KTD di Delapan Propinsi - Pulau Sumatera, Project Report, Program Mampu, Jakarta, hlm. 23; 150; 156; 195; 339

20 Dewi Candraningrum, et al., "Takut Akan Zina, Pendidikan Rendah, dan Kemiskinan: Status Anak Perempuan dalam Pernikahan Anak di Sukabumi Jawa Barat", Jurnal Perempuan 88, Vol. 21, No.1, Februari 2016.

21 Ini temuan penelitian di desa di Jawa Barat (bagian 4), tetapi ini gejala yang juga ditemukan di banyak daerah lain.

22 Kehamilan yang tidak dikehendaki: perempuan bertutur (Mampu, 2015). Kompilasi studi kasus PERMAMPU tentang KTD, naskahnya disiapkan Sita van Bemmelen dalam rangka Program Mampu, AUSAID, 2014.

23 Sikap pemerintah itu terlihat dalam kasus seorang anak perempuan yang dinikahkan pada usia 8 tahun di Aceh pada tahun 1891 , kemudian diperkosa oleh suaminya sampai harus dirawat selama tiga bulan. Suaminya dijatuhkan hukuman penjara oleh pengadilan setempat (Landraad) tetapi vonis itu dihapus oleh Pengadilan Tinggi (Hoge Raad) di Batavia, lihat Sita van Bemmelen \& Mies Grijns, Op.cit, hlm. 324-6. 
pemerintah sudah merombak sistem pendidikan dan berbagai tipe sekolah baru didirikan.

Namun demikian, pemerintah tidak tinggal diam. Pada tahun 1915 revisi KUHP diberlakukan dimana Pasal 288 berbunyi sebagai berikut: “(1) Barang siapa yang bersenggama dengan seorang perempuan (dimaksud istri) dalam perkawinan, yang diketahui atau yang dapat diduga belum dapat diajak berhubungan suami-istri (huwbaar), akan dihukum penjara paling lama 4 tahun; (2) Apabila (persetubuhan) itu mengakibatkan luka dapat divonis penjara paling lama 8 tahun; (3) Apabila menyebabkan kematian hukuman penjara paling lama 12 tahun" (Wetboek van Strafrecht voor Nederlandsch Indië 1915:78-79). Tujuan Pasal ini adalah melindungi anak perempuan terhadap "penyempurnaan" perkawinan (consummation of the marriage) atau berhubungan seksual, sebelum istri mendapatkan haid pertamanya (masuk pubertas). Kebiasaan atau adat masyarakat di Jawa untuk menunda hubungan seksual sampai saat itu - yang dikenal dengan istilah kawin gantung ${ }^{24}$ sudah diketahui pemerintah, antara lain dari laporan penelitian tentang kurangnya kesejahteraan. Bahwa Pasal 288 itu sulit diterapkan masuk akal. Pertama, tidak jelas siapa yang bisa melaporkan kasus ini, berbeda dengan kejadian pemerkosaan seorang anak perempuan di luar nikah yang disebut delik aduan dalam Pasal 287. Akan tetapi apakah orang tua atau orang lain mau melaporkannya setelah anak perempuan sudah dinikahkan secara sah? ${ }^{25}$

Namun, pamong praja di Jawa sudah mengetahui tentang Pasal 288 di KUHP yang baru dan beberapa diantara mereka mulai bergerak. Di Jawa Tengah ditempel suatu poster di tiap masjid dengan pesan bahwa anak perempuan hanya boleh menikah apabila sudah mencapai umur 16 tahun. Bupati Priangan, Raden Adipati Ario Winata Koesoema, memerintahkan bawahannya yang bertugas pada tingkat desa untuk mencegah perkawinan anak. Tetapi karena kebijakan ini tidak diikuti oleh bupati di kabupaten tetangga, orang tua tetap bisa mengawinkan anaknya di tempat lain. Orang tua juga mencari jalan lain untuk mengelakkan regulasi. Dalam satu kasus, orang tua menghadirkan anak mereka yang berusia 18 tahun sebagai pengantin perempuan saat akad nikah, tetapi selanjutnya dia digantikan dengan adiknya yang baru 10 tahun, karena anak kecil itulah yang sebenarnya ingin dinikahi oleh pengantin laki-laki.

Walaupun pada tahun 1920 sudah ada anggota parlemen di Belanda yang bertanya soal legislasi terkait perkawinan anak di Hindia Belanda, baru pada tahun 1925 pemerintah kolonial atas nama Gubernur Jenderal D. Fock mengirim instruksi kepada seluruh jajaran residen untuk melawan perkawinan anak. Meskipun demikian, mereka diminta bertindak dengan hati-hati karena pemerintah tidak punya rencana melarangnya (Surat 14-12-1925, No. 403). Selain itu, mereka diharuskan mengirim laporan ke pusat setiap enam bulan tentang jumlah perkawinan anak yang dilangsungkan di daerah mereka menjabat.

Ternyata implementasi kebijakan itu tidak berjalan dengan mulus. Terhambatnya kebijakan ini disebabkan oleh beberapa hal. Pertama, intervensi wedana, lurah, dan penghulu dinilai sebagai sebuah penghinaan karena membatasi kekuasaan penuh seorang ayah untuk mengawinkan anaknya. Kedua, pemeriksaan terhadap pengantin perempuan (oleh para pejabat laki-laki ini) untuk menentukan apakah anak perempuan yang bersangkutan sudah cukup umur dianggap sebuah pelanggaran kesopanan, apalagi bila menyangkut pemeriksaan fisik. Masalah lain lagi biasanya orang tua sudah mempersiapkan segala-galanya untuk pesta perkawinan sebelum perkawinan dilangsungkan dan para tamu sudah diundang. Mudah terbayang betapa jengkel dan marahnya para orangtua yang akan menikahkan anak mereka saat pejabat pemerintah menekan

24 Penjelasan tentang kawin gantung lebih rinci tentang tradisi ini lihat bagian 4 .

25 Susan Blackburn \& Sharon Bessell, "Marriageable Age: Political Debate on Early Marriage in Twentieth-Century Indonesia", Indonesia, No. 63, 1997, hlm. 113. Elsbeth Locher-Scholten, 2000, Women and the Colonial State: Essays on Gender and Modernity in the NetherlandsIndies 1900-1942, Amsterdam University Press, Amsterdam, hlm. 193. 
sang penghulu untuk menolak melangsungkan akad nikah.

Peran penghulu memang problematis, karena dia tidak selalu punya kesempatan untuk memverifikasi apakah calon pengantin perempuan sudah cukup umur atau belum. Persoalannya, tidak ada patokan yang pasti yang bisa dipakainya. Dokumen identitas hukum berupa akte kelahiran hanya wajib dimiliki olehorang yang berstatus Eropa, sehingga tidak ada jalan lain daripada menebak usia para pengantin berdasarkan pengamatan semata. Penghulu juga punya kepentingan pribadi untuk tetap memfasilitasi perkawinan anak: mereka akan menerima uang dan/atau hadiah berupa barang untuk jasa mereka dari pihak keluarga yang mengawinkan anak mereka. Problem lain lagi: pada bulan setelah bulan Ramadhan, permintaan atas jasa mereka meningkat, sehingga mungkin mereka kurang waktu untuk pemeriksaan umur setiap pasangan pengantin. Pendek kata, implementasi peraturan surat edaran tersebut menyebabkan ketegangan antara pamong praja dengan penghulu dan - apabila seorang penghulu menaati aturan antara dia dan masyarakat desa. Kisah di bawah ini tentang keadaan saat ini di desa di Jawa Barat memperlihatkan situasi yang masih mirip.

Perkembangan ini kemudian menarik perhatian para pemimpin Muhammadiyah. Mereka memutuskan untuk mengkaji isi Al Qur'an dan hadits tentang perkawinan anak untuk mencari tahu apakah perkawinan anak sebagaimana dilaksanakan di Jawa bertentangan dengan kedua sumber hukum Islam itu. Kami menggarisbawahi disini bahwa kebijakan pemimpin Muhammadiyah menunjukkan bahwa mereka mengakui secara tersirat bahwa perkawinan anak adalah suatu adat Jawa yang mungkin saja tidak selaras dengan substansi Al Qur'an. Pemimpin sayap politik Islam, Partai Sarikat Islam (PSI) melalui suara pemimpinnya H.O.S. Tjokroaminoto sangat menantang politik penjajah terkait perkawinan anak. ${ }^{26}$ Pemerintah memutuskan untuk menangguhkan surat edarannya: para bupati, wedana dan lurah tidak diperbolehkan mengintervensi lagi. Pemerintah menyerahkan menekan tingkat perkawinan anak kepada organisasi pribumi dan pers pribumi.

Walaupun keadaan sebelum tahun 1925 secara de facto berlaku kembali, pada akhir episode ini telah terjadi suatu penggeseran maha besar. Suara umat Muslim menjadi sedemikian nyaring sampai Pemerintah Belanda beserta pamong praja di bawahnya mengurungkan niat untuk melanjutkan rencana tersebut. Sekali lagi, karena hasil yang tidak sepadan masalah politik yang ditimbulkannya, pemerintah kolonial berhenti memperjuangkan penghapusan perkawinan anak. Mengingat bahwa pandangan nasionalisme juga semakin menguat dan memanaskan suhu politik Hindia Belanda, sikap pemerintah saat itu dapat dipahami. Terlebih lagi, pemimpin PSI juga berhasil mengemas kebiasaan perkawinan adat sebagai praktek yang didukung Islam, bahkan bagian dari identitas Muslim. Mereka sekaligus membawa pesan bahwa pantang sebuah pemerintah "kafir" ikut campur urusan umat Islam seperti perkawinan anak. Politisasi isu perkawinan anak dipakai PSI untuk menguatkan citranya sebagai partai yang membawa identitas agama Islam. Semenjak itulah pemahaman tentang perkawinan anak sebagai sebuah kebiasaan tradisional Indonesia semakin luntur. Malah fakta bahwa perkawinan anak juga merupakan adat di daerah di mana mayoritas penduduk tidak beragama Islam sama sekali tidak pernah diangkat dalam debat publik.

Di kalangan kaum perempuan, pandangan mengenai perkawinan anak pada akhir dasawarsa 1920 dan sepanjang 1930an memperlihatkan betapa beragam posisi yang diambil terhadap isu ini, baik terkait boleh-tidaknya perkawinan anak dilakukan maupun pengemasannya. Misalnya pada Kongres Perempuan Pertama tahun 1928 wakil organisasi Poetri Indonesia Moegaroemah mengajak para hadirin sebagai berikut: 'Mari kita melawan 'adat-

26 Mungkin pemicunya adalah kehilangan muka salah satu pemimpinnya di daerah Jawa Barat karena penghulu setempat menolak perkawinannya karena pengantin perempuan masih terlalu muda, lihat Sita van Bemmelen \& Mies Grijns, Op.cit., hlm. 333. 
istiadat' bangsa kita yang buruk'. Dia menambahkan bahwa dia tidak menganggap dirinya kompeten membahas perkawinan anak dari sudut pandang agama Islam. ${ }^{27}$ Tahun berikutnya, PSI menyatakan Al Qur'an tidak melarang perkawinan anak, sehingga PSI juga tidak bisa melarangnya. Muhammadiyah juga mengambil posisi yang menarik dengan menyatakan bahwa perkawinan anak diizinkan namun pasangan belum boleh hidup bersama sampai anak tersebut cukup umur. Artinya, Muhammadiyah mengakui dan bersedia mengintegrasikan kebiasaan kawin gantung sebagai bagian dari pedoman yang berlaku untuk umatnya. Pada Kongres PSI tahun 1930, Ketua Aisyah mengeluarkan pernyataan yang berani karena menantang posisi yang diambil Muhammadiyah, organisasi induknya. Meskipun menurut Islam perkawinan anak memang diizinkan, Aisyah menolak perkawinan anak karena anak perempuan belum sanggup memikul kewajiban sebagai seorang ibu yang bertugas mendidik anaknya dan sebagai ibu yang mampu mengurus rumah tangganya dengan baik.

Pada tahun 1937 pemerintah kolonial yang saat itu berniat mewujudkan unifikasi hukum di segala bidang, mengajukan Rancangan UndangUndang Perkawinan untuk seluruh warga Hindia Belanda, termasuk pilihan untuk melangsungkan perkawinan sipil. Artinya, pemeluk agama Islam dapat mendaftarkan perkawinan mereka di Kantor Catatan Sipil, tetapi hanya untuk perkawinan monogami. ${ }^{28}$ Rancangan legislasi ini juga menetapkan usia perkawinan minimum 15 tahun untuk perempuan dan 18 tahun untuk laki-laki.

Rancangan itu, termasuk usia minimum perkawinan, ditolak oleh semua organisasi Islam dan proto parlemen (Volksraad) karena beberapa alasan yang berkaitan dengan norma Islam. ${ }^{29}$ Jalan buntu ini, kemungkinan besar, memicu Kongres
Perempuan tahun 1938 untuk mengangkat topik ini lagi. Maria Ulfah Santoso (kemudian disebut Soebadio), seorang nasionalis dan sarjana hukum perempuan pertama yang lulus dari fakultas hukum universitas Leiden, membuat agenda untuk melakukan revisi undang-undang perkawinan agar dapat diterima semua pihak. Namun, masa penjajahan berakhir tanpa menghasilkan undangundang perkawinan untuk umat Islam. Undangundang perkawinan yang berhasil ditetapkan pada tahun 1936 hanya berlaku untuk umat Kristiani, dengan ketentuan mengenai usia minimum seperti usulan di atas. ${ }^{30}$

Dapat disimpulkan bahwa kegagalan pemerintah kolonial untuk memberantas perkawinan anak berkaitan erat dengan tidak adanya kesepakatan tentang konsep hukum terkait anak dan kedewasaan. Pemerintah kolonial menggunakan patokan umur tertentu untuk melangsungkan perkawinan: menurut hukum sipil Belanda usia perkawinan minimal untuk perempuan adalah 15 tahun dan untuk laki-laki minimal 18 tahun, dengan syarat bahwa anak di bawah 21 tahun memerlukan persetujuan dari orang tua atau walinya. Apabila umur anak yang bersangkutan di bawah batasan yang telah ditetapkan, orang tua sang anak masih diberikan kesempatan untuk minta persetujuan Gubernur Jenderal (Burgerlijk Wetboek 1847, Pasal 4 (85), 93-104).

Sementara itu, masyarakat di Jawa dan Madura tidak mengenal batas usia sama sekali - pada tahun 1915 dilaporkan bahwa anak anak perempuan menikah pada usia 7 sampai 15 tahun dan anak lakilaki antara 14 sampai 20 tahun. Masyarakat hanya mengenal konsep kawin gantung yang mengizinkan persetubuhan hanya setelah anak perempuan sudah mendapatkan haid pertamanya. Apakah orang tua anak perempuan selalu mengindahkan kebiasaan itu,

27 Susan Blackburn, 2007, Kongres Perempuan Pertama. Tinjauan Ulang, Yayasan Pustaka Obor Indonesia, Jakarta, hlm. 49-53.

28 Stijn Cornelis van Huis, 2015, Islamic Courts and Women's Divorce Rights in Indonesia: The Cases of Cianjur and Bulukumba, Disertasi, Leiden University, Leiden, hlm. 79-80.

29 Susan Blackburn \& Sharon Bessell, Op.cit., hlm. 125-126.

30 Huwelijksordonnantie Christen-Indonesiers Java, Minahasa en Amboina, Staatsblad 1933, No. 74. Melalui Staatsblad 1936, No. 607 peraturan ini ditetapkan untuk seluruh umat Kristen Katolik di Indonesia, mulai berlaku per 1 januari 1937. 
pada akhirnya hanya tinggal pertanyaan. Sementara itu, tokoh Islam juga merujuk pada patokan akil baligh yang pada dasarnya sama dengan kawin gantung. Seorang anak dianggap dewasa apabila sudah menikah. Upaya pemerintah kolonial menurunkan perkawinan anak juga gagal karena pendekatannya yang terlalu top-down. Serangkaian hambatan yang ditemukan saat pelaksanaan di lapangan menunjukkan bahwa pemerintah kolonial gagal mengantisipasi perlawanan yang terjadi di tingkat lokal. Situasi ini merupakan temuan penting karena mirip dengan hambatan yang masih ditemukan hingga saat ini (lihat kasus Jawa Barat di bawah).

Tidak lama setelah kemerdekaan pemerintah Indonesia mulai mempertimbangkan regulasi terkait perkawinan. Langkah pertama ke arah itu adalah introduksi Undang-Undang No. 22 Tahun 1946 tentang pencatatan perkawinan, perceraian, dan rujuk untuk umat Islam di Jawa dan Madura. Delapan tahun kemudian, peraturan ini diberlakukan untuk masyarakat Islam di seluruh wilayah Indonesia melalui Undang-Undang Nomor 32 Tahun 1954. Pada saat itu juga terbentuk Kantor Urusan Agama (KUA) dan Pengadilan Agama khusus untuk penduduk yang beragama Islam. Sementara itu, Kantor Catatan Sipil dan Pengadilan Negeri diperuntukkan untuk semua penduduk Indonesia yang beragama selain Islam. Di bawah pengarahan Kementerian Agama yang juga dibentuk pada tahun 1946, para pemuka agama Islam, Kristen, Katolik dan agama lain, mulai mempersiapkan rancangan Undang-Undang Perkawinan, yang disajikan pada DPR Desember 1952. Gagasan di belakangnya adalah untuk menciptakan satu undang-udang terkodifikasi yang berlaku untuk semua, dengan mengesampingkan perbedaan-perbedaan berdasar- kan agama, suku dan kelas seperti pada masa penjajahan. Rancangan menetapkan persetujuan perkawinan, usia perkawinan minimum 15 tahun untuk anak perempuan dan 18 untuk anak laki-laki, dan poligami terbatas. ${ }^{31}$ Sebenarnya butuh waktu bertahun-tahun untuk menginisiasi undang-undang perkawinan yang dapat berlaku secara nasional, dengan banyak rancangan yang pembahasannya terus-menerus ditunda-tunda DPR. ${ }^{32}$ Seiring dengan upaya tersebut, kebijakan pemerintah kolonial yang terpusat pada hukum adat digugurkan. Pada tahun 1951, semua pengadilan adat ditiadakan dan pada tahun 1960 Mahkamah Agung memisahkan Islam dan adat komunitas lokal. ${ }^{33}$ Kemungkinan besar itu dilakukan untuk mempertahankan dukungan dari Nahdatul Ulama (NU), yang waktu itu masih berbentuk partai politik Islam.

Isu perkawinan anak muncul kembali walaupun secara tidak langsung - dalam kebijakan Keluarga Berencana pada masa pemerintahan Suharto (Orde Baru). Perkawinan anak dianggap sebagai kebiasaan yang bertentangan dengan tujuan untuk mewujudkan 'keluarga sejahtera'. ${ }^{34}$ Rancangan undang-undang perkawinan berikutnya, meskipun didukung oleh partai Golkar dan PDI, ternyata belum bisa diketok palu dalam pembahasan di DPR tahun 1973. Rancangan itu ditolak mentahmentah oleh organisasi Muslim dengan mengadakan demonstrasi besar-besaran karena dipandang sebagai serangan pada agama Islam sendiri. ${ }^{35}$ Salah satu masalah kontroversial adalah usia perkawinan minimum yang diusulkan - 18 tahun untuk perempuan dan 21 untuk laki-laki - batas usia yang diilhami oleh kebijakan keluarga berencana. Pasal 7 ayat (1) UU Perkawinan mencerminkan kesepakatan yang akhirnya ditemukan. Sebagai usia minimum untuk perempuan diterima 16 tahun dan

31 Maria Ulfah Soebadio, Perjuangan untuk mencapai Undang-Undang Perkawinan: Ceramah, tanggal 28 Februari 1981 di Gedung Kebangkitan Nasional Jakarta, Yayasan Idayu, Jakarta, hlm. 15.

32 Susan Blackburn \& Sharon Bessell, Op.cit., hlm. 131, lihat juga Maria Ulfah Soebadio, Ibid., hlm. 17.

33 Stijn Cornelis van Huis, Op.cit., hlm. 45-46.

34 Tujuan utama Program Keluarga Berencana adalah menekan laju pertumbuhan penduduk yang dianggap menghambat kemajuan dan peningkatan kesejahteraan masyarakat (perhatikan bahwa kebijakan ini mirip kebijakan pemerintah kolonial pada awal abad ke-20 yang disebut di atas).

35 Stijn Cornelis van Huis, Op.cit., hlm. 47-48, dan lihat juga Maria Ulfah Soebadio, Op.cit., hlm. 17-20. 
19 tahun untuk lak-laki, dengan persyaratan izin orang tua masih diperlukan. Baru pada saat seorang perempuan dan seorang laki-laki berumur 21 tahun mereka dianggap dewasa dan diperbolehkan menikah tanpa persetujuan orang tua. Untuk mencegah perkawinan paksa, UU Perkawinan juga menetapkan di Pasal 6 ayat (1) bahwa perkawinan berdasarkan persetujuan kedua belah pihak. ${ }^{36} \mathrm{UU}$ Perkawinan telah membuat terobosan hukum yang sangat berarti bagi anak perempuan Muslim, karena sebelumnya perkawinan mereka di bawah umur dan perkawinan yang diatur oleh wali mereka tanpa persetujuan mereka sendiri diperbolehkan menurut fiqh $h^{37} \cdot{ }^{38}$ UU perkawinan diberlakukan pada tanggal 1 Oktober tahun 1975 dan masih berlaku sampai hari ini. ${ }^{39}$

Proses kelahiran UU Perkawinan memperlihatkan upaya, yang pada akhirnya gagal, untuk membentuk unifikasi hukum perkawinan. Hukum agama, hukum adat dan hukum perdata Barat memang diakomodasi dalam UU tersebut. Namun hukum perkawinan ternyata tidak dapat diwujudkan tanpa pemisahan antara substansi dan sistem hukum untuk umat Islam di satu sisi dan umat beragama lain di sisi lain. Sebagaimana telah diutarakan Susetyo unifikasi hukum bukan perkara yang gampang, karena selamanya unifikasi di wilayah hukum pribadi dan hukum keluarga adalah sesuatu yang sulit. ${ }^{40}$ Betapa sulitnya menemukan kesepakatan antara lain terlihat dalam berulang kalinya usia perkawinan minimum diubah dalam rancangan UU Perkawinan sampai 1974.

Selama dasawarsa berikutnya para pejuang hak perempuan terus menyuarakan kritik terhadap ketentuan dalam UU Perkawinan yang mereka anggap bersifat diskriminatif. Kritik dilontarkan antara lain tentang perbedaan usia perkawinan minimum untuk perempuan dan laki-laki, ketentuan tentang laki-laki sebagai kepala keluarga, persyaratan bahwa seorang wali harus berjenis kelamin laki-laki, dan pembedaan antara laki-laki dan perempuan terkait hak cerai dan poligami. ${ }^{41}$ Terlepas dari dukungan perempuan dan lakilaki Muslim liberal, usul untuk menaikkan umur perkawinan minimum terus menerus bertemu dengan keberatan dari pihak Muslim konservatif. Untuk mengakomodasi umat Islam pemerintah mengembangkan pedoman untuk para hakim di Pengadilan Agama. Hasilnya Kompilasi Hukum Islam (KHI) yang dimasukkan banyak peraturan UU Perkawinan didalamnya. KHI diratifikasi melalui Instruksi Presiden pada tahun 1991 dan mendorong Pengadilan Agama untuk lebih merujuk pada UU ini daripada fiqh tradisional. ${ }^{42}$

Pada Era Reformasi beberapa kali ada usaha untuk revisi hukum keluarga Islam substantif, antara lain mengenai poligami dan usia perkawinan. Rancangan UU yang disebut the Counter Legal Draft (CLD) diajukan tahun 2004 dan menawarkan alternatif yang paling progresif untuk Kompilasi Hukum Islam, yang akan "menyelaraskan hukum keluarga Muslim dengan kesetaraan perempuan dan laki-laki yang telah dijamin dalam Konstitusi". ${ }^{43}$ Di bawah arahan Musdah Mulia, seorang pembela hak perempuan yang terhormat, revisi penting dimasukkan di CLD. Pembaruan penting yang relevan untuk perkawinan anak dalam CLD ialah anjuran tentang usia minimum perkawinan

36 Lihat Pasal 6 ayat (1) Undang-Undang Nomor 1 Tahun 1974 tentang Perkawinan (Lembaran Negara Republik Indonesia Tahun 1974 Nomor 1, Tambahan Lembaran Negara Republik Indonesia Nomor 3019).

37 Fiqh berarti doktrin Islam, dalam kehidupan sehari-hari digunakan sebagai istilah untuk hukum Islam.

38 Stijn Cornelis van Huis, Op.cit., hlm. 89 dan 112.

39 Untuk semua kasus yang tidak diatur di UU Perkawinan, seperti perkawinan campur antar orang yang menganut agama yang berbeda atau berbeda kebangsaan, peraturan hukum berikut masih berlaku: Burgerlijk Wetboek, Huwelijks Ordonantie Christen Indonesiërs S. 1933 No. 74; Regeling op de Gemengde Huwelijken S. 1898 No. 158, lihat Maria Ulfah Soebadio, Op.cit., hlm. 53.

40 Hero Susetyo, "Pernikahan di Bawah Umur: Tantangan Legislasi dan Harmonisasi Hukum", https://search.hukumonline.com/id/search/ browse? $q=$ Heru + Susetyo, diakses 4 Desember 2014.

41 Kathryn Robinson, "Muslim Women's Political Struggle for Marriage Law Reform in Contemporary Indonesia", dalam Amanda Whiting \& Carolyn Evans, 2006, Mixed Blessings. Laws, Religions, and Women's Rights in the Asia-Pacific region, Martinus Nijhoff Publishers, Leiden, hlm. 202-203.

42 Ibid.

43 Stijn Cornelis van Huis, Op.cit., hlm. 108. 
19 tahun untuk kedua calon mempelai, serta persyaratan untuk mencatatkan semua perkawinan agar sah. ${ }^{44}$ Sekali lagi, masalah poligami (poligini) mencuatkan perdebatan yang paling sengit. CLD secara resmi ditarik pada tahun 2005, karena menimbulkan terlalu banyak kontroversi. Reaksi keras terhadap upaya-upaya untuk merevisi hukum ini menunjukkan bahwa mengubah 'keseimbangan' antara hukum Islam, hukum negara, dan hukum adat adalah tugas maha berat. ${ }^{45}$

Sementara itu, pemerintah Indonesia sudah mulai memperhatikan hak asasi manusia melalui ratifikasi beberapa Konvensi Internasional. Baik CEDAW (Konvensi PBB tentang Penghapusan Segala Bentuk Diskriminasi Terhadap Perempuan) yang diratifikasi tahun 1984 dan CRC (Konvensi tentang Hak-Hak Anak) tahun 1990 relevan dalam rangka perjuangan penghapusan perkawinan anak. ${ }^{46}$ CRC dan Undang-Undang Nomor 23 Tahun 2002 tentang Perlindungan Anak menyatakan bahwa anak adalah mereka yang berusia di bawah 18 tahun. Namun, sampai saat ini umur perkawinan minimum tetap 16 tahun untuk anak perempuan sebagaimana ditetapkan di UU Perkawinan. Dengan demikian, perkawinan perempuan yang berumur 16 dan 17 tahun sebenarnya perkawinan anak yang dilegalkan negara (legalised child marriage).

Akhir-akhir ini protes dari pihak perempuan dapat dukungan dari para aktivis hak anak. Pada tahun 2014 koalisi dua kelompok ini mengajukan permohonan pada Mahkamah Konstitusi untuk melakukan uji materi (judicial review) UU Perkawinan. Pokok permohonan dalam perkara Nomor 30-74/ PUU-XII/2014 ini adalah untuk menaikan batas umur minimal bagi perkawinan anak perempuan menjadi 18 tahun. ${ }^{47}$ Para hakim konstitusi mengesampingkan argumen-argumen tentang dampak negatif perkawinan yang diajukan ahli beragama Islam dan non-Islam, dan menolak permohonan uji materi tersebut. Mereka memilih mengacu pada akil baligh yang merupakan standar hukum Islam sebagai ukuran kedewasaan dan umur yang cukup untuk menikah daripada mengacu pada umur minimum yang pasti. ${ }^{48}$

Hal yang menarik dari Putusan Mahkamah Konstitusi Nomor 30-74/ PUU-XII/2014 terhadap judicial review mengenai usia perkawinan untuk anak perempuan, adalah testimoni dari para tokoh agama non-Muslim. ${ }^{49}$ Mereka semua setuju dengan usia minimal 18 untuk perkawinan perempuan. Tokoh Kristen dan Buddha menyebut usia 18 sebagai batas kedewasaan. Pemuka agama Hindu menyebut usia antara 18-21 untuk perempuan. Berbeda halnya dengan pemuka agama Khonghucu yang menandai kondisi akil baligh perempuan dengan penggunaan tusuk konde pada umur 15 , dan penggunaan topi pada lelaki pada usia 20, tetapi usia nikah baru dianggap mapan pada usia 20 untuk perempuan dan 30 untuk laki-laki.

Tahun 2017 judicial review lain diprakarsai (Nomor 22/PUU-XV/2017), kali ini oleh tiga perempuan muda yang telah menikah saat mereka

44 Ibid, hlm. 106-107.

45 Ibid., hlm. 113.

46 Konvensi tentang Kesepakatan untuk Menikah, Umur Minimum Menikah dan Pencatatan Pernikahan (Convention on Consent to Marriage, Minimum Age for Marriage and Registration of Marriages) 1964 menyebutkan bahwa negara peserta konvensi ini akan mengupayakan lahirnya legislasi untuk mengatur permasalahan umur minimum untuk menikah dan bahwasanya pernikahan yang dilakukan di luar umur minimum yang ditetapkan adalah tidak berkekuatan hukum, terkecuali wewenang menetapkan dispensasi tertentu dengan alasan yang wajar dengan mengedepankan kepentingan pasangan yang akan menikah. Indonesia belum menjadi negara pihak dari Konvensi 1964 tersebut, namun telah menetapkan usia minimum pernikahan, serta kesepakatan untuk menikah, pencatatan pernikahan dan kemungkinan untuk minta dispensasi, melalui UU No. 1 Tahun 1974 tentang Perkawinan, alias sepuluh tahun setelah Konvensi tersebut lahir, lihat Hero Susetyo, "Pernikahan di Bawah Umur: Tantangan Legislasi dan Harmonisasi Hukum”, https://search.hukumonline.com/id/search/browse? $q=H e r u+S u s e t y o$, diakses 4 Desember 2014.

47 Lihat Putusan Mahkamah Konstitusi Nomor 30-74/ PUU-XII/2014 perihal Pengujian Undang-Undang Nomor 1 Tahun 1974 tentang Perkawinan terhadap Undang-Undang Dasar Negara Republik Indonesia Tahun 1945, 18 Juni 2015.

48 Lihat YPHA, 2015, "Pernyataan Sikap Koalisi 18+ Atas Keputusan MK", http://www.ypha.or.id/web/?p=1608, diakses 4 Februari 2017. Hanya satu dari sembilan hakim Mahkamah Konstitusi yang tidak mendukung keputusan tersebut, yaitu satu-satunya hakim perempuan, Maria Farida Indrati (non-Muslim). Dia merujuk ke hak asasi manusia dan pembangunan, lihat Grijns, Mies \& Horii, Hoko, "Child Marriage in a Village in West Java (Indonesia): Compromises between Legal Obligations and Religious Concerns", Asian Journal of Law and Society, 2018, hlm. 5 .

49 Putusan Mahkamah Konstitusi Nomor 30-74/ PUU-XII/2014 perihal Pengujian Undang-Undang Nomor 1 Tahun 1974 tentang Perkawinan terhadap Undang-Undang Dasar Negara Republik Indonesia Tahun 1945, 18 Juni 2015, hlm. 168. 
masih remaja. Dengan dukungan dari aktivis perempuan mereka menuntut umur perkawinan minimum yang sama untuk anak perempuan dan anak laki-laki, berdasarkan prinsip kesetaraan gender yang dijamin dalam Konstitusi. Mereka menginginkan bahwa umur perkawinan minimum perempuan disamakan dengan umur perkawinan minimum laki-laki di dalam UU Perkawinan, yaitu 19 tahun. Ternyata mendengarkan langsung dari remaja yang pernah mengalami perkawinan pada usia muda, memberi hakim MK inspirasi untuk mengabulkan permohonan tersebut. ${ }^{50}$

Perkembangan baru lain datang dari kalangan organisasi perempuan Islam. Pada tanggal 27 April 2017, Kongres Perempuan Ulama Indonesia (KUPI) pertama, yang dihadiri sekitar 1000 ulama perempuan, mengeluarkan tiga fatwa, salah satu diantaranya mengenai perkawinan anak. Fatwa ini menyebutkan perkawinan anak sebagai praktek yang berbahaya dan juga menyatakan bahwa pencegahannya merupakan kewajiban. Para ulama perempuan mendesak pemerintah untuk meningkatkan umur perkawinan minimum menjadi 18 tahun. Fatwa mereka sangat berseberangan dengan pendapat pemimpin agama di MUI, yang mayoritas anggotanya adalah laki-laki. Menteri Agama Lukman Hakim Siafuddin langsung menyambut fatwa KUPI. Menteri Agama berjanji akan menyalurkan rekomendasinya kepada Menteri
Pemberdayaan Perempuan dan Perlindungan Anak, Yohannya Yembise, agar pemerintah merancang amendemen UU Perkawinan. ${ }^{51}$ Sebenarnya sebuah Perppu tentang pencegahan perkawinan anak sudah lama dipersiapkan melalui kerja sama dengan sejumlah organisasi perempuan ${ }^{52}$. Presiden Jokowi pada bulan April 2018 sempat menunjukkan komitmennya untuk mendorong pengesahan Perppu tentang pencegahan perkawinan anak ini. ${ }^{53}$ Tetapi hingga saat ini komitmen tersebut belum ditindaklanjuti. Sementara itu para aktivis memilih untuk mengubah haluan advokasinya dan memilih strategi yang kini terlihat lebih berhasil, yaitu upaya mendorong keluarnya peraturan daerah tentang pencegahan perkawinan anak. ${ }^{54}$ Hal yang menarik adalah hukum adat lokal masih dipakai di dalamnya, misalnya adat merariq di Lombok Barat. ${ }^{55}$

Uraian di atas menampilkan aspek perdata dari perkawinan anak, tetapi juga ada beberapa peraturan hukum pidana yang bertalian dengannya. Pasal 288 di revisi KUHP 1915 tentang 'bersetubuh dengan istrinya tapi belum masanya dikawinkan' masih berlaku. Pada masa penjajahan aturan hukum ini dirumuskan untuk melindungi anak perempuan yang melakukan kawin gantung. Tetapi seperti disebut Susetyo, "Kalaupun terjadi tindak pidana dalam perkawinan seperti disebut Pasal 288 KUHP, seringkali masalah diselesaikan secara perdata saja atau tidak sama sekali. ${ }^{56}$ Sebab, karena

50 Putusan Mahkamah Konstitusi Nomor 22/PUU-XV/2017 Perihal Pengujian Undang-Undang Nomor 1 Tahun 1974 tentang Perkawinan terhadap Undang-Undang Dasar Negara Republik Indonesia Tahun 1945, 13 Desember 2018: Mahkamah Konstitusi mempertimbangkan bahwa umur 16 tahun sebagai batas usia minimum bagi perkawinan anak perempuan merupakan diskriminasi yang berbasis gender dan bersifat inkonstitusional. Putusan ini juga mengakui hak bagi anak perempuan atas pendidikan, kesehatan dan kesejahteraan. Untuk menindaklanjuti putusan ini, MK memerintahkan pembentuk undang-undang untuk melakukan revisi atas Undang-Undang Nomor 1 Tahun 1974 tentang Perkawinan (UU Perkawinan) dalam waktu 3 tahun sejak putusan dijatuhkan. Apabila pembentuk undang-undang tidak menyelesaikan perubahan UU Perkawinan sesuai waktu yang ditentukan, ketentuan mengenai batas usia minimum dalam UU Perkawinan akan disesuaikan dengan Undang-Undang Nomor 23 tahun 2002 tentang Perlindungan Anak. Hal ini berarti bahwa usia minimum untuk melangsungkan perkawinan adalah 18 tahun. Lihat juga: The Jakarta Post, "Breaking: Court Orders Revisions of Minimum Age for Women to Marry", http:// www.thejakartapost.com/news/2018/12/13/breaking-court-orders-revision-of-minimum-age-for-women-to-marry.html.

51 Nurul F. Ramadhani dan Ati Nurbaiti, "Avoiding child marriage "mandatory", http://www.thejakartapost.com/news/2017/04/28/avoidingchild-marriage-mandatory.htmli, diakses tanggal 29 April 2017.

52 Dian Kartikasari, 2016, Kearah Perppu Anti Perkawinan Anak, Tim KPPA, Jakarta.

53 Eva Mazrieva, "Jokowi Setuju Dorong Pengesahan Perppu Pencegahan Perkawinan Anak", https://www.voaindonesia.com/a/jokowi-setujudorong-pengesahan-perppu-pencegahan-perkawinan-anak/4358431.html, diakses tanggal 23 April 2018.

54 Misalnya mulai dari Peraturan Bupati Gunung Kidul Nomor 36 Tahun 2015 tentang Pencegahan Perkawinan Pada Usia Anak sampai Peraturan Gubernur Bengkulu No. 33 Tahun 2018 tentang Pencegahan Perkawinan Anak. Dan masih terus ada yang sedang dipersiapkan di lain daerah.

55 Lihat Evi Sukmayeti, "Bingkai Merariq Menurut Awig-Awig dan Praktik Perkawinan Anak dalam Masyarakat Sasak Labuapi" dalam Mies Grijns, et al., 2018, Menikah Muda di Indonesia: Suara, Hukum dan Praktik, Yayasan Pustaka Obor Indonesia, Jakarta.

56 Hero Susetyo, "Pernikahan di Bawah Umur: Tantangan Legislasi dan Harmonisasi Hukum", https://search.hukumonline.com/id/search/ browse? $q=$ Heru + Susetyo, diakses 4 Desember 2014. 
mempertimbangkan rahasia ataupun kehormatan rumah tangga, seringkali pihak istri atau keluarganya tidak melaporkan kekerasan tersebut entah karena alasan takut, aib keluarga, atau kesulitan dalam menghadirkan alat bukti”. Penelitian di Jawa Barat menemukan bahwa pada generasi perempuan lanjut usia yang menikah pada umur 9-10 tahun kebiasaan kawin gantung tidak diindahkan (lihat bagian 4). Tidak pernah ada yang memikirkan sanksi, karena hukum adat tentang itu tidak ada, dan tidak ada satupun yang mengetahui tentang aturan tersebut di KUHP.

Dari pemaparan di atas dapat diambil dua kesimpulan. Pertama, ketidakselarasan hukum menyangkut pandangan yang berbeda tentang usia minimal perkawinan terus berlangsung. Kedua, Pemerintah Indonesia sangat disibukkan dengan legislasi dan harmonisasi hukum demi pencegahan perkawinan di bawah umur dan itu membawa beberapa hasil positif. UU Perkawinan mengatur dua unsur penting: (1) Perkawinan adalah sah, apabila dilakukan menurut hukum masing-masing agamanya dan kepercayaannya itu; dan (2) Tiap-tiap perkawinan dicatat menurut peraturan perundangundangan yang berlaku. ${ }^{57}$ Jelaslah, ayat-ayat ini merupakan kompromi untuk memenuhi keinginan semua kelompok agama. Setidaknya melalui kewajiban pendaftaran perkawinan, negara akhirnya dapat menjamin sebagian besar - meskipun belum semua - perkawinan untuk menjadi perkawinan yang sah, walaupun realisasinya masih juga tergantung pada implementasi peraturan di tingkat bawah.

Pada masa yang akan datang, beberapa kebijakan yang mendukung upaya penghapusan perkawinan anak kemungkinan akan semakin berkembang. Instrumen hukum yang melandasi kebijakan tersebut dapat ditemukan misalnya pada ${ }^{58}$ Undang-Undang Nomor 23 Tahun 2002 tentang Perlindungan Anak. Pasal 2 (1) UU ini menyebutkan bahwa, "Orang tua berkewajiban dan bertanggung jawab untuk: (c) mencegah terjadinya perkawinan pada usia anak-anak". ${ }^{59}$ Pemerintah juga sudah berkomitmen untuk mencapai Tujuan Pembangunan Berkelanjutan (TPB, terjemahan dari Sustainable Developments Goals/SDG) pada tahun 2030 melalui Perpres Nomor 59 tahun 2017. Tujuan Nomor 5.3 menyangkut penghapusan perkawinan anak di bawah 18 tahun.

Bila perkembangan terkait perkawinan anak ditinjau kembali, triangle Gustav Radbruch ${ }^{60}$ dapat dipakai sebagai pisau analisa. Dari pemaparan di atas dapat disimpulkan bahwa kebijakan terkait perkawinan anak melalui peraturan hukum tidak pernah terwujud. Pemerintah kolonial mempertimbangkannya tetapi tidak pernah berani menetapkan peraturan tentang usia perkawinan yang pasti, kecuali untuk bagian masyarakat pribumi yang beragama Kristen dan Katolik. Pengemasan perkawinan anak oleh pemerintah kolonial sebagai adat yang didukung pamong praja dan kaum perempuan dari kalangan tersebut tidak diterima kalangan partai politik dan organisasi Islam beserta tokohnya. Pemerintah Indonesia memang sudah berhasil menetapkan usia perkawinan minimal 16 tahun untuk perempuan dan 19 untuk laki-laki dalam UU Perkawinan, tetapi itupun tidak berhasil menghapus perkawinan anak.

Setelah Reformasi perubahan melalui revisi UU Perkawinan diupayakan lagi, tetapi sekali lagi pemerintah menghadapi tantangan yang kurang lebih sama dengan yang dihadapi pemerintah kolonial, sehingga belum ditemukan titik temu hingga saat ini. Hal ini dapat terjadi karena tidak adanya pemahaman yang sama tentang konsep anak dan usia yang pantas untuk menikah. Ternyata, legislasi yang dimaksudkan untuk merekayasa suatu keadaan baru yang diinginkan justru cenderung sarat dengan pertaruhan politik. Jelaslah, pendekatan yang

\footnotetext{
57 Pasal 2 ayat (1) dan (2) Undang-Undang Nomor 1 Tahun 1974 tentang Perkawinan (Lembaran Negara Republik Indonesia Tahun 1974 Nomor 1, Tambahan Lembaran Negara Republik Indonesia Nomor 3019).

58 Undang-Undang Nomor 23 Tahun 2002 tentang Perlindungan Anak (Lembaran Negara Republik Indonesia Tahun 2002 Nomor 109 , Tambahan Lembaran Negara Republik Indonesia Nomor 4235).

59 Lihat Adriaan Bedner, Op.cit., hlm. 2-3.

60 Ibid., hlm. 6-7.
} 
bersifat legalistik yang lazim digunakan kalangan akademisi dan penegak hukum, serta didukung juga sebagian aktivis perempuan dan anak, tidak bisa dengan sendirinya mengatasi masalah sosial seperti perkawinan anak (dan kemungkinan besar masalah sosial lain di ruang lingkup keluarga juga). Alhasil, kepastian hukum (legal certainty), satu pilar sebuah sistem hukum menurut Radbruch, tidak pernah tercapai.

Kesimpulan kedua adalah bahwa dari upaya legislasi terkait perkawinan anak selalu mengutamakan pilar sistem hukum kedua menurut Radbruch, yaitu manfaat sosial dan juga ekonomi (social utility). Pemerintah kolonial maupun pemerintah Orde Baru dan pemerintahan Jokowi belakangan ini menempatkannya dalam kerangka besar pembangunan negara dan peningkatan kesejahteraan rakyat. Namun, itupun gagal dicapai. Pilar sistem hukum ketiga, yaitu keadilan (justice) juga muncul dalam debat ini. Dari zaman kolonial sampai sekarang, upaya berbagai pihak untuk menghasilkan legislasi yang melindungi anak perempuan dari perkawinan pada usia muda dan untuk menjamin haknya untuk mengambil keputusan sendiri tentang perkawinan juga, tidak kunjung berhasil.

Persoalan dalam isu ini tidak hanya terletak pada tidak selarasnya substansi hukum saja. Tidak kalah pentingnya adalah kegagalan implementasi substansi hukum ini oleh penegak hukum di lapangan dan tantangan yang berasal dari keberlanjutan budaya hukum yang mendarah daging di masyarakat, terutama di pedesaan. Dapat dipahami bahwa UU Perkawinan yang menentukan usia minimum perkawinan baru berlaku kurang dari setengah abad yang lalu. Hingga saat ini masih banyak yang menganggap UU Perkawinan sebagai 'hukum asing'. UU Perkawinan mereka anggap dapat diabaikan keberlakuannya atau, bila dipaksakan, boleh dilewati melalui pemalsuan umur supaya perkawinan itu terlihat masih dalam koridor peraturan perundang-undangan. Tujua isbath nikah sama. Atau mereka memilih untuk melangsungkan perkawinan di luar koridor hukum negara melalui kawin siri. Bentuk resistensi di masyarakat bawah berbeda-beda, karena berhubungan dengan adat dan hukum adat lokal yang berbeda-beda pula. Inilah topik untuk kajian hukum adat dengan pendekatan interdisipliner. Kasus tentang keberlanjutan praktek perkawinan anak di Jawa Barat (bagian 4) dan perubahannya di Tapanuli Utara (bagian 5) adalah dua contoh pendekatan tersebut.

\section{Perkawinan Anak yang Bertahan di Pede- saan Jawa Barat, Kabupaten Sukabumi}

Jawa Barat sejak dulu termasuk daerah dengan kasus perkawinan anak yang tertinggi di Indonesia, ${ }^{61}$ khususnya di antara kalangan Muslim di daerah Pasundan. Sekarang ini Jawa Barat menempati peringkat 14 dari 34 provinsi dalam daftar peringkat propinsi menurut prevalensi perkawinan usia anak. ${ }^{62}$ Sebenarnya untuk memahami gejala perkawinan anak tidak cukup untuk hanya membandingkan prevalensi per provinsi. Menurut BPS apabila memperhatikan data per kabupaten dan kecamatan ".. prevalensi perkawinan anak perempuan yang sangat tinggi terdapat di kantong-kantong geografis di seluruh Indonesia". ${ }^{63}$

Kasus sebuah desa di Jawa Barat yang kami angkat di sini membuktikan keragaman angka perkawinan anak. ${ }^{64}$ Desa ini terletak di kabupaten

61 Gavin Jones, “Which Indonesian Women Marry Youngest, and Why?” Journal of Southeast Asian Studies, Vol. 32, No. 1, Februari 2001, hlm. 69-71.

62 Sekarang ini persentase perempuan usia 20-24 yang pernah menikah di bawah usia 18 dari seluruh pulau Jawa hanya Jawa Timur (24.40\%) bersama Jawa Barat (23,8\%) ada diatas persentase rata-rata se Indonesia (22.91\%) (berdasarkan Susenas 2017 dalam BPS 2018 ). Bagi perkawinan perempuan di bawah usia 16 Susenas menemukan 6\% rata-rata untuk seluruh Indonesia pada kurun waktu 2008-2012. Jawa Barat masih relatif tinggi dibanding propinsi lain: rata-rata 7,8\%. Lihat BPS, 2016, Kemajuan yang Tertunda: Analisis Data Perkawinan Usia Anak di Indonesia, Badan Pusat Statistik, Jakarta.

63 Lihat BPS, 2016, Kemajuan yang Tertunda: Analisis Data Perkawinan Usia Anak di Indonesia, Badan Pusat Statistik, Jakarta, hlm. 39.

64 Sumber bagian ini berdasarkan Mies Grijns, et al (2016), Mies Grijns \& Hoko Horii (2018) dan catatan lapangan. Desa ini dipilih karena peneliti sudah akrab dengan penduduk dari masa penelitian sebelumnya, jadi akses kepada anak muda yang melakukan perkawinan di bawah umur lebih terjamin. Lagipula konteks agama Islam yang cukup bervariasi di desa ini ternyata juga penting karena kaitannya dengan perkawinan anak. 
Sukabumi yang mana baik kabupaten maupun kecamatannya dimana desa ini berlokasi tidak termasuk dalam daerah dengan prevalensi tinggi. Pada tahun 2014 kami melakukan survey di desa tersebut untuk melihat prevalensi perempuan dan laki-laki pada rentang usia 20-24 tahun yang pernah menikah. Hasil survey menunjukkan bahwa persentase perempuan yang melakukan perkawinan pertamanya pada usia di bawah 18 tahun $35 \%$ dan untuk laki-laki sebesar $4,3 \%$. Persentase perempuan yang sudah menikah di bawah usia 16 tahun hanya sebesar 7,3\%. Hal ini berarti bahwa perkawinan anak perempuan paling banyak terjadi pada rentang usia 16 tahun dan 17 tahun. Jadi perkawinan anak di desa ini masih bertahan walaupun sudah masuk 'zaman now'.

Keadaan sekarang sudah jauh berubah dibanding zaman penjajahan: waktu itu anak perempuan menikah di Jawa antara 7 dan 15 tahun, sekarang mayoritasnya menikah sebagai remaja (16 keatas). Apakah itu juga berarti adat Sunda yang dulu sudah berubah? Menurut Buttenheim dan Nobles tidak terjadi perubahan signifikan dalam pola perkawinan muda pada 10 kelompok etnis yang masuk dalam penelitian statistik mereka selama separuh abad keduapuluh terakhir. ${ }^{65}$ Khusus untuk suku Sunda, mereka menemukan bahwa norma dan perilaku perkawinan anak secara konsisten dipraktekkan pada usia terendah (bersama dengan suku Bugis), walaupun memang saat ini usia perkawinan secara pelan-pelan sudah meningkat seperti halnya di kelompok etnis lain.

Apakah dulu ada adat Sunda yang mendukung perkawinan pada usia muda? Soepomo melakukan penelitian tentang hukum perdata di Jawa Barat pada tahun 1931-1932 dan mencatat "di seluruh wilayah hukum sahnya perkawinan diatur menurut hukum Islam". ${ }^{66}$ Jadi hukum Islam dianggap paling penting, bukan hukum adat. Menurut Soepomo "perkawinan anak-anak" terjadi di seluruh Jawa Barat. ${ }^{67}$ Soepomo juga masih menemukan tradisi perkawinan anak yaitu kawin gantung yang sering terjadi. ${ }^{68}$ Konsep kawin gantung ini merujuk pada perkawinan antara dua anak yang belum dewasa yang masih tetap tinggal bersama orang-tua masingmasing dan berada di bawah kuasa mereka. Upacara akad nikah telah dilangsungkan, tetapi suamiisteri belum hidup bersama sebagai suami-isteri. Persetubuhan ditunda sampai anak perempuan sudah akil baligh, lagipula sampai orang-tua kedua belah pihak sudah sanggup merayakan pesta perkawinan, atau upacara temu (pertemuan antara mempelai perempuan dan mempelai lelaki). Selain itu, ada perkawinan antara seorang anak perempuan yang belum dewasa dan belum akil baligh dengan seorang lelaki dewasa, yang membawa konsekuensi mereka akan langsung tinggal serumah, yaitu di rumah orang tua perempuan. Perkawinan itu dikenal dengan istilah mungut mantu, kawin pacul, dan lain-lain. Menantu yang mondok di rumah mertuanya diperlakukan sebagai tenaga pembantu di rumah atau di kebun, yang tidak perlu dibayar.

Muncul pertanyaan siapa yang dianggap anak dan siapa dewasa menurut adat Sunda? Soepomo menjelaskan bahwa tidak ada petunjuk bahwa hukum adat Jawa Barat mengenal batas umur yang pasti kapan anak menjadi dewasa; hal itu hanya dapat dilihat dari ciri-ciri yang nyata. ${ }^{69}$ Seorang dianggap dewasa sejak kuat gawe (dapat bekerja); kuat mengurus harta bendanya dan keperluanluan lainnya, dapat berdiri-sendiri, melindungi kepentingannya sendiri dan ikut serta dalam kehidupan hukum dan sosial di lingkungannya. Menurut hukum adat mencapai usia 21 tidak

65 Tujuan penelitian mereka adalah untuk menjawab pertanyaan sejauh mana perubahan ekonomi dan hukum membawa perubahan dalam norma dan perilaku terkait perkawinan, penjelasan lebih lanjut lihat Alison Buttenheim \& Jenna Nobles, "Ethnic Diversity, Traditional Norms, and Marriage Behaviour in Indonesia", Population Studies, Vol. 63, No. 3, 2009.

66 Soepomo, Raden, 1967, Hukum Perdata Adat Djawa Barat. Diterdjemahkan oleh Nj. Nani Soewondo SH (dari Het adatprivaatrecht van West-Java, 1933), Djambatan, Djakarta, hlm. 30.

67 Banten waktu itu masih termasuk Jawa Barat.

68 Soepomo, Raden, Op.cit., hlm. 50.

69 Ibid., hlm. 25-26. 
ada artinya, berbeda dengan peraturan tentang pendewasaan menurut ${ }^{70}$ Staatsblad 1931 Nomor 54 yang mencantumkan batas usia tersebut. Kesan kami batas usia kuat gawe ini lebih menjelaskan ciri dewasa seorang anak lelaki dibandingkan anak perempuan. Ketika bicara tentang ciriciri kedewasaan perempuan, hanya disebut akil balighnya. Kebiasaan khusus satu lagi adalah selama belum kawin, meskipun telah dewasa, perempuan tetap tinggal di rumah orangtuanya dan ada di bawah pengawasan orangtuanya. Kesimpulannya, konsep anak di dalam hukum perdata adat Sunda mengandung unsur gender dan tidak pakai umur yang pasti.

Apakah adat kawin gantung masih berlaku di Sukabumi sekarang ini? Yang jelas perkawinan anak yang disebut kawin pacul oleh Soepomo, sudah lama tidak dipakai. Ruang lingkup masyarakat desa sudah berubah dari daerah perkebunan teh dan ladang, dari kebun pribadi menuju ke era industrialisasi desa. Namun, kawin gantung yang berarti kedua anak dijodohkan orangtuanya pada usia muda, masih pernah dialami oleh generasi yang sekarang sudah kakek nenek. Tetapi dengan meningkatnya usia perkawinan pertama di generasigenerasi berikutnya, sekarang ini anak perempuan yang belum akil baligh jarang dijodohkan lagi. Itu hanya masih terjadi dalam rangka kawin kontrak dengan pasangan seorang laki-laki dewasa, seperti misalnya di Indramayu dan Cirebon, atau nikah mu'tah. Nikah mu'tah dilangsungkan di wilayah Bogor (Puncak), dimana anak perempuan yang masih (sangat) muda diserahkan sebagai pengantin pada wisatawan laki-laki dari Timur Tengah.

Nampaknya dalam perkawinan di Sunda hukum adat tidak terlalu penting lagi. Ketika ditanya tentang adat mereka, orang desa memberikan jawaban seperti "Islam adalah adat kita", sebuah jawaban yang sesuai pengamatan Soepomo dulu. Tetapi ternyata masih ada beberapa kebiasaan seputar perkawinan. Selain norma tentang usia yang pantas untuk menikah (akil baligh), masih berlaku norma tentang umur maksimumnya, dan juga pandangan bahwa pelamaran tidak boleh ditolak oleh pihak perempuan. Sampai belum lama ini umur maksimal yang diterima masyarakat adalah 18 tahun untuk anak perempuan. Sekarang norma itu perlahan-lahan naik dengan akses pada pendidikan yang meningkat dan lebih terbukanya akses pada pekerjaan pabrik.

Alasan untuk menikah juga sedang berubah. Seperti telah disebut di bagian 2, agensi remaja muda adalah gejala baru, didorong mobilitas mereka, baik secara fisik maupun digital. Hubungan suka-sama-suka dianggap cool (keren) oleh murid SMP dan SMA. Walaupun ini sepertinya gejala baru, tetapi sebenarnya seabad yang lalu Wilken dan Ossenbruggen telah memakai istilah sukasama-suka dan telah mencatat kebebasan seksual anak perempuan, dengan syarat mereka menikah sebelum melahirkan bayi. ${ }^{71}$ Dalam beragam jenis perkawinan anak yang ditemukan oleh Mies Grijns et al., (2016) ancaman kehamilan di luar nikah dan ketakutan pada zina merupakan alasan utama mengapa remaja perempuan (didorong untuk) menikah pada usia muda. ${ }^{72}$ Perkawinan mereka tidak selalu dicatatkan dengan alasan mereka bisa bercerai dengan mudah apabila hubungan mereka tidak berjalan dengan baik di kemudian hari. Perceraian bukan hal tabu dalam budaya hukum adat Sunda dan remaja masih diberi ruang untuk mengambil keputusan bercerai bila belum ada anak. Bedner dan van Huis mengamati, bahwa budaya itu juga mengizinkan remaja di daerah perdesaan kebebasan seksual relatif leluasa. ${ }^{73}$ Kendati perkawinan anak sekarang jelas dibingkai sebagai

70 George Alexander Wilken, \& Frederik Daniel Eduard van Ossenbruggen, 1912, De Verspreide Geschriften van Prof. Dr. G.A. Wilken, Van Dorp, Semarang, hlm. 262-264.

71 Lihat Mies Grijns, et al., "Pernikahan Anak Di Sukabumi Jawa Barat: Diri Dan Agensi Anak Perempuan (English translation expected end 2018 as Child Marriage in Sukabumi West Java: Self and Agency of Girls)", Jurnal Perempuan 88, Vol. 21, No.1, Februari 2016.

72 Adriaan Bedner \& Stijn van Huis, "Plurality of Marriage Law and Marriage Registration for Muslims in Indonesia: A Plea for Pragmatism", Utrecht Law Review, Vol. 6, No. 2, Juni 2010, hlm. 188.

73 Perkawinan usia anak adalah "perkawinan yang dilakukan melalui hukum perdata, agama atau adat, dan dengan atau tanpa pencatatan atau persetujuan resmi dimana salah satu atau kedua pasangan adalah anak di bawah usia 18 tahun". 
praktek Islam, tampaknya masih ada tanda-tanda adat Sunda yang mentolerir hubungan seksual pranikah.

Tantangan dari sudut pandang hukum adalah sebagai berikut. Substansi hukum negara dan interpretasi agama Islam tidak sejalan. Menurut hukum negara anak perempuan berusia minimal 16 tahun boleh menikah, tetapi menurut pandangan lokal akil baligh lebih penting. Perkawinan di bawah umur biasanya 'diatur' di tingkat desa. Perkawinan sebagai solusi untuk keadaan darurat (kehamilan yang tidak diinginkan, apalagi kelahiran bayi di luar pernikahan) dipentingkan dalam konteks pandangan lokal tanpa mencari solusi yang mempertimbangkan hak-hak anak, seperti hak belajar dan hak bermain. Legal literacy atau pemahaman atas hukum masih kurang. Saat para responden dan informan diwawancara hampir tidak ada anak remaja atau orangtua yang tahu tentang peraturan tentang usia perkawinan dan hak persetujuan si anak. Dampaknya jarang ada orang tua yang datang ke Pengadilan Agama (PA) untuk minta dispensasi usia untuk anaknya. Bahkan tidak ada satu pun kasus dari desa ini yang pernah ke PA, baik untuk dispensasi, isbat nikah atau perceraian dini.

Perlu dicatat bahwa angka perkawinan anak berusia 16 dan 17 tahun yang dicatat di KUA setempat lebih rendah daripada angka yang diterbitkan BPS. Salah satu sebabnya BPS memakai definisi perkawinan anak yang lebih luas daripada KUA. ${ }^{74}$ Alasan lainnya adalah bahwa tidak semua perkawinan anak dicatatkan oleh KUA. Horii mengkalkulasi bahwa Pengadilan Agama hanya menangani permohonan dispensasi sekitar $8 \%$ dari semua perkawinan anak perempuan di bawah umur $16 .{ }^{75}$ Hanya perkawinan anak dengan dispensasi yang dapat dicatat oleh petugas KUA dan memperoleh buku nikah. Dalam kasus lain, rendahnya data kasus perkawinan anak di KUA juga disebabkan karena orang tua tidak mengajukan permohonan dispensasi sebagaimana seharusnya. Pertanyaan yang timbul: bagaimana mungkin orang tua tetap berhasil menikahkan anak mereka meskipun di bawah umur yang ditetapkan UU?

Ternyata semua itu ditangani oleh aktor lokal. Untuk menjalankan perkawinan dibawah umur, kepala desa dan amil di desa seolah "bersekongkol" untuk memfasilitasi perkawinan anak dengan menambahkan usia anak dari yang seharusnya, melakukan penundaan pencatatan nikah atau melangsungkan isbat nikah di luar PA. Masih banyak anak yang dinikahkan yang tidak milik akte kelahiran sebagai bukti legal identity, sehingga gampang terjadi pemalsuan umur. Penegak hukum di tingkat KUA tidak mau ambil pusing dengan memverifikasi surat-surat, karena semua menganggap aktor lokal telah menyediakan dokumen yang 'siap-pakai'. Dengan demikian sanksi tidak perlu dijatuhkan. Lagipula, petugas KUA sendiri juga bersikap permisif. Menurut mereka, hal itu dilakukan demi kebutuhan masyarakat (social utility). Mereka menyampaikan bahwa yang penting adalah kebaikan/ keuntungan dari pencatatan perkawinan, seperti akses kepada KTP, KK, program raskin, dll.

Perkawinan yang tak dicatatkan, seperti nikah siri, memang bukan tanpa resiko. Kerugian utama menimpa pihak istri dan anak-anak yang dilahirkan dalam perkawinan tersebut. Apabila istri tidak memiliki buku nikah, maka ia akan kesulitan mengklaim hak-haknya selaku istri terkait dengan

74 Ini merupakan hasil temuan Hoko Horii yang dapat dilihat di Mies Grijns \& Hoko Horii, "Child Marriage in a Village in West Java (Indonesia): Compromises between Legal Obligations and Religious Concerns", Asian Journal of Law and Society, 2018, hlm. 7. Untuk mendapatkan izin perkawinan anak mereka, orang tua harus mengajukan permohonan kepada Pengadilan Negeri atau Pengadilan Agama, tergantung agama mereka. Beberapa peneliti menemukan bahwa 90\% permohonan dispensasi dikabulkan oleh hakim, seringkali dengan merujuk kepada ketakutan orang tua anaknya akan berzina, yaitu terjebak dalam hubungan seksual pra-nikah, lihat Hoko Horii, 2015, Uncovering Difficulties in the Implementation of International Human Rights Laws in the Indonesian Pluralistic Legal System: Issue of Child Marriage in West Java, Master Thesis, Nagoya University, Nagoya; Mark Evenhuis, \& Jeniffer Burn, 2014, Just Married, Just a Child: Child Marriage in the Indo-Pacific Region, Plan International Australia, Melbourne; dan Supriadi Widodo Eddyono, et al., 2016, Menyingkap Tabir Dispensasi Perkawinan: Analisis Terhadap Praktik Perkawinan Anak di Kab. Tuban, Kab. Bogor, dan Kab. Mamuju, Koalisi 18+, Jakarta.

75 Susetyo, Hero, "Pernikahan di Bawah Umur: Tantangan Legislasi dan Harmonisasi Hukum", https://search.hukumonline.com/id/search/ browse? $q=$ Heru + Susetyo, diakses 4 Desember 2014. 
masalah perceraian, warisan, tunjangan keluarga, dan lain-lai)!

Kesimpulan dari kasus ini adalah bahwa perkawinan pada usia dini sebenarnya tidak lagi isu hanya melekat pada Jawa Barat. Argumentasi ini didasarkan pada kenyataan bahwa kawin gantung sudah nyaris menghilang dan mulai diganti dengan keragaman modus perkawinan anak, khususnya yang dilakukan atas dasar keinginan remaja sendiri. Upaya apapun untuk membenahi persoalan hukum terkait perkawinan anak dan untuk mendukung reformasi hukum, perlu memperhitungkan peran besar dari tokoh adat dan agama serta keragaman dalam praktek perkawinan anak modern. Keragaman itu menuntut legislasi yang fleksibel dan tepat sasaran. Mampukah pembentuk hukum dan aparat hukum mengkritisi dan melahirkan legislasi di wilayah hukum perkawinan yang menjamin perlindungan hukum bagi semua pihak dan pada saat bersamaan tetap melahirkan keadilan?

\section{Strategi Menurunkan Umur Perkawinan: Kasus Batak Toba (Tapanuli Utara)}

Pada tahun 1997 Buttenheim dan Nobles menemukan bahwa di suku Batak baik norma adat tentang usia minimum maupun dalam praktek perkawinan sekitar dua tahun di atas yang ditemukan untuk suku Sunda. ${ }^{76}$ Perbedaan itu berlanjut sampai sekarang. Dalam daftar peringkat provinsi menurut prevalensi rata-rata perkawinan usia anak Propinsi Sumatera Utara menempatkan peringkat 31 dari 34 propinsi: rata-rata $14,66 \%$ perempuan kelompok usia 20-24 tahun yang pernah menikah melakukan perkawinan pertamanya sebelum umur 18 tahun. ${ }^{77}$ Hanya di DIY, DKI Jakarta dan Aceh persentase itu lebih rendah. Persentase perempuan yang menikah di bawah umur 16 tahun per tahun selama periode 2008-2012 juga lebih rendah dibanding propinsi lain: rata-rata 2,5\% ${ }^{78}$ Memang masih ada beberapa kecamatan di Provinsi Sumatera Utara yang tercatat memiliki prevalensi perkawinan anak yang cukup tinggi, ${ }^{79}$ namun demikian tidak ada satupun kecamatan tersebut yang terletak di Kabupaten Tapanuli Utara, Samosir, dan Humbang Hasundutan. Ketiga kabupaten ini kurang lebih merupakan wilayah yang kebanyakan dihuni orang Batak Toba, dengan mayoritas agama yang dianut adalah Kristen. Padahal, sebelum korporasi Zending Jerman (Rheinische Missionsgesellschaft, RMG) masuk pada tahun 1861, perkawinan anak juga merupakan kebiasaan masyarakat Batak Toba. Hal ini membawa kita pada pertanyaan: mengapa kebiasaan itu sempat menghilang. ${ }^{80}$

Sama dengan korporasi zending dan misi Katolik di tempat lain, para misionaris RMG mulai memperkenalkan kebiasaan baru seperti pembaptisan, kewajiban hadir saat khotbah pada hari Minggu, dan kewajiban orang tua untuk menyekolahkan anaknya. Orang Kristen baru juga tidak diperbolehkan mengikuti lagi upacara agama tradisionalnya yang lama. Upaya misionaris untuk merekayasa suatu masyarakat 'Kristen Batak' yang mengacu pada hukum, norma dan nilai yang mereka bawa dari negara asal, pada akhirnya berdampak juga pada adat-istiadat dan hukum adat.

Satu kebiasaan yang ditemukan missionaris waktu awal kristianisasi adalah perjodohan anak oleh orang tua berdasarkan serangkaian kepentingan seperti mempererat ikatan dengan marga lain melalui ulangan perkawinan generasi sebelumnya; diplomasi elit adat yang didasarkan pada kebutuhan bersekutu dengan marga lain dalam keadaan perang; dilakukan oleh para pedagang untuk membangun

76 Alison Buttenheim \& Jenna Nobles, "Ethnic Diversity, Traditional Norms, and Marriage Behaviour in Indonesia", Population Studies, Vol. 63 , No. 3, 2009, hlm. 282.

77 Angka ini berdasarkan Susenas 2017. Persentase macam ini dapat cukup bervariasi per tahun. Sebagai contoh, menurut Susenas 2016 Sumatera Utara adalah propinsi dengan prevalensi perkawinan anak yang terendah dengan persentase 12,95\%. Lihat BPS, "Perkawinan Usia Anak di Indonesia (Kajian dari Data Susenas BPS)", Presentasi oleh Gantjang, Direktorat Statistik Kesejahteraan Rakyat, dalam Dialog Publik "Data Berbasis Gender dan Inklusif', Institut KAPAL Perempuan, Jakarta, 24 September 2018.

78 BPS, 2016, Op.cit., hlm. 40 dan 58.

79 Ibid., hlm. 63-64.

80 Sumber narasi tentang proses penurunan perkawinan anak adalah Bemmelen, 2018, Op.cit: hlm. 74-86; 94-100; 57-273. 
kepercayaan dengan mitra bisnis mereka; dan juga dipraktekkan oleh rakyat miskin untuk melepaskan diri dari hutang dengan memperhitungkan hutang tersebut sebagai bagian dari sinamot (bride price) yang harus dibayar untuk anak perempuan. Bahkan anak yang masih di kandungan ibu bisa dijodohkan (apabila ternyata anak perempuan). Namun, tidak semua anak perempuan dijodohkan pada usia yang masih sangat muda. Terhadap anak perempuan dan anak laki-laki, diadakan ritual potong gigi saat mereka masuk pubertas. Budaya Batak lama kaya pepatah dan puisi, termasuk puisi yang diucapkan anak perempuan yang baru dipotong giginya. Isinya, mengundang laki-laki untuk mendekatinya karena dia sudah 'matang'. ${ }^{81}$ Atau mereka masih diberi kesempatan untuk ikut pertemuan pemuda yang tujuannya adalah menemukan calon pasangan. Berpacaran juga disertai tukar-menukar tanda dan dapat bermuara pada kehamilan. Oleh seorang raja Batak Kristen pada akhir abad kesembilanbelas hubungan seksual di luar nikah saat pacaran disebut "dosa anak muda" yang menunjukkan bahwa raja ini sudah menginternalisir norma Kristen tentang kesucian seorang perempuan.

Misionaris yang hidup di tengah umat Kristen baru, mengamati bahwa anak perempuan biasanya segara dikawinkan setelah ritual potong gigi, pada usia yang mereka anggap masih terlalu muda. Pada tahun 1874 rapat tahunan mereka menetapkan bahwa untuk pemberkatan di gereja sebaiknya pasangan sudah cukup dewasa (mature). Tahun 1881 mereka mengeluarkan Peraturan Gereja (Church Ordinance) yang menetapkan batas usia minimum yang cukup tinggi: untuk anak perempuan 18 tahun dan untuk anak laki-laki 20 tahun. Pada tahun 1886 dibuat kompilasi peraturan hukum adat untuk orang Kristen bersama dengan para raja marga Kristen di Silindung, yang dikukuhkan pemerintah Belanda pada tahun 1892. Salah satu peraturannya menyangkut usia perkawinan yang diturunkan menjadi 16 tahun untuk anak perempuan dan 18 tahun untuk anak laki-laki. Kemungkinan besar itu dilakukan supaya usia minimum sama dengan usia minimum yang tercantum dalam Kode Sipil Belanda yang berlaku untuk anak bangsa Eropa.

Orang tua Batak dan juga pemuda-pemudi tidak langsung menerima adat Kristen baru. Ritual potong gigi tidak hilang begitu saja. Misionaris jijik melihat anak-anak yang giginya dipotong, karena berwarna hitam dan mulutnya merah karena mereka sudah mulai makan sirih pinang. Mereka sempat melarang ritual itu antara 1885-1892, juga dengan maksud mencegah perkawinan anak. Tetapi kemudian mereka memakai strategi lunak dengan memperkenalkan aturan baru: anak-anak dapat diterima dalam Konfirmasi sebagai anggota jemaat setelah mereka lulus sekolah dasar dan setelah mengikuti ajaran agama selama dua tahun. Setelah Konfirmasi acara potong gigi diperbolehkan. Tetapi lama-kelamaan kebiasaan ini ditinggalkan, karena orang tua Kristen merasa bahwa mengadakan ritual tersebut tidak pantas lagi. Rupanya kombinasi aturan dan kebijakan ini cukup berhasil menaikkan umur pernikahan anak perempuan. Menurut inspektor dari RMG yang berkunjung ke Tapanuli tahun 1900 kebanyakan anak perempuan Kristen menikah tidak lama setelah dikonfirmasi, artinya kira-kira saat mereka 15 tahun. Dalam hal ini peran para pendeta dan guru jemaat lulusan seminari di Pancur na Pitu juga berpengaruh: kepatuhan mereka dalam pelaksanaan peraturan terjamin, karena mereka bergantung pada misionaris untuk jabatan dan gaji mereka.

Para misionaris juga ingin mencegah kehamilan di luar nikah, antara lain karena itu dapat menyebabkan masalah adat antar dua keluarga terkait. Perempuan harus maju ke pelaminan dalam keadaan masih perawan. Dalam rangka mendorong anak muda supaya menahan dorongan seksual mereka diperkenalkan sebuah penghargaan

81 Pantunnya berbunyi: [anak perempuan] "Gigi saya sudah dipotong kemarin, kamu tahu itu sakit. Tetapi walaupun wajah saya bengkak, silahkan mendekati saya, saya sudah siap (tang)" (Karl Helbig, "Einige Bemerkungen über die Sittlichen Zustãnde und die Erotik der TobaBatak auf Sumatra", Baesler Archiv, Vol.18, 1935, terjemahan oleh Sita van Bemmelen dari Bahasa Belanda). 
bagi pasangan Kristen yang tidak bersenggama sebelum menikah, sudah dikonfirmasi dan sudah cukup umur. Perkawinan mereka dapat diberkati di gereja oleh seorang misionaris berkulit putih atau, pilihan kedua, seorang pendeta Batak. Apabila syarat itu belum dipenuhi, perkawinan hanya dapat diberkati oleh seorang guru jemaat. Sedangkan mereka yang diketahui sudah pernah berhubungan badan apalagi bila perempuan hamil, akan terkena sanksi bertubi-tubi. Mereka tidak dilarang hadir kebaktian hari Minggu, tetapi mereka harus duduk di tempat terpisah. Rasa malunya bisa dibayangkan. Mereka juga tidak diizinkan berpartisipasi dalam perayaan Perjamuan Kudus dan anak mereka tidak bisa dibaptis. Peraturan itu masih berlaku di gereja HKBP sampai saat ini. ${ }^{82}$ Lambat laun kombinasi penghargaan dan sanksi ini merupakan strategi yang cukup efektif untuk menaikkan umur perkawinan dan mencegah kehamilan di luar nikah.

Kebiasaan baru yang lain juga membantu menaikkannya secara tidak langsung. Tanggal pembaptisan anak tercantum di buku catatan jemaat gereja, sehingga ada patokan untuk menentukan apakah anak sudah cukup umur. ${ }^{83}$ Kewajiban untuk mengumumkan rencana perkawinan tiga kali di pintu gereja pada hari Minggu berturutturut, berarti pemimpin gereja punya waktu untuk verifikasi apakah calon pengantin memenuhi syarat perkawinan. Misionaris juga menjunjung tinggi persetujuan masing-masing pengantin. Artinya, apabila anak perempuan dipaksa menikah dia punya kesempatan untuk menolak calon pengantin sebagai suaminya saat pemberkatan di gereja. Kemungkinan besar itu jarang sekali terjadi, tetapi paling sedikit aturan ini menanamkan norma tentang hak pilih seorang anak. Dalam kompilasi hukum adat hasil kerja sama misionaris dan raja Batak Kristen juga tercantum sanksi terhadap seorang laki-laki yang menculik perempuan dengan maksud menjadikan istrinya. Apabila perempuan itu tidak mau, penculiknya harus menerima sanksi lebih berat dibanding kalau perempuan itu tidak berkeberatan (masalahnya, tidak jarang perempuan yang diculik langsung diperkosa, sehingga dia tunduk saja). Penculikan perempuan tidak dilarang dalam hukum adat, tetapi selalu disertai pembayaran denda yang harus dibayar pada bapak si perempuan. Di samping itu, keluarga pelaku penculikan harus menjamu kerabatnya sebagai tanda minta maaf, karena wewenang bapaknya atau walinya untuk menikahkannya telah dilangkahi.

Kesimpulannya, kasus Batak Toba menunjukkan bahwa peningkatan umur perkawinan diwujudkan melalui kombinasi strategi yang cukup kompleks. Langkah pertama adalah penetapan peraturan gereja dan hukum adat yang baru dan berlaku untuk umat Kristen. Kebiasaan adat tertentu juga turut diubah seperti: momentum tertentu dalam kehidupan seorang anak dikonstruksikan untuk dapat meningkatkan umur perkawinan; anak dari keluarga Kristen wajib sekolah 5 tahun, dan mengikuti kelompok ajaran agama selama dua tahun saat menginjak pubertas. Setelah melalui semua tahap itu, seseorang baru dapat diterima sebagai anggota jemaat dan baru kemudian boleh menikah. Saat ini, strategi 'non-hukum' seperti itu juga dipertimbangkan melalui program wajib belajar 12 tahun. Kemudian terkait pemberkatan perkawinan di gereja juga menerapkan sistem rewards and sanctions: pemberkatan bergengsi hanya terbuka bagi pasangan Kristen yang memenuhi semua syarat, sedangkan di ujung spektrum lain ada perkawinan yang hanya bisa disahkan oleh tokoh adat saja.

Persamaan antara kasus Jawa Barat dan kasus Toba Batak adalah besarnya peran pemimpin agama dalam menentukan perkawinan anak. Meskipun demikian, peran pemimpin agama di kedua daerah tersebut sangat berbeda. Di Jawa Barat, masyarakat berpegang pada hukum Islam yang mengizinkan perkawinan anak sepanjang anak perempuan sudah datang bulan (akil baligh). Kondisi ini lazim

82 Keterangan Nurseli Deborah Manurung, dosen di Sekolah Tinggi Bibelfrau (STB-HKBP), Laguboti.

83 Anak tidak selalu dibaptis dalam waktu beberapa hari setelah lahir. Ada orang tua yang menunggu sampai anaknya ternyata bertahan hidup. 
terjadi di bawah usia 15 tahun. Amil dan perangkat desa memegang peran penting untuk mengurus perkawinan anak ini di KUA. Sementara itu pada akhir masa penjajahan, pendeta Batak, yang memimpin gereja HKB semenjak 1930, beserta guru jemaat telah biasa memberkati perkawinan pasangan dengan memperhatikan syarat umur perempuan minimal 16 tahun dan umur laki-laki 18 tahun. Keadaan itu dikukuhkan pula oleh peraturan pemerintah kolonial tentang perkawinan untuk umat Kristen yang diberlakukan semenjak 1937. Hal ini menunjukkan bahwa masyakarat Batak Toba sudah lama menginternalisir norma tentang umur minimal perkawinan, bahkan jauh sebelum batas umur perkawinan dibahas dalam legislasi perkawinan sebelum kemerdekaan. Dari aspek umur minimal untuk melangsungkan perkawinan, dapat dilihat bahwa budaya hukum masyarakat Batak Toba tidak berseberangan dengan substansi UU Perkawinan 1974. Keadaan yang sama kemungkinan juga terjadi di kalangan umat Kristen yang lain.

\section{Kesimpulan}

Kesimpulan yang dapat ditarik dari uraian di atas adalah bahwa kajian hukum adat, khususnya dalam bidang hukum keluarga, masih tetap relevan sepanjang kajian tersebut memperhatikan dinamika yang terjadi dalam medan pertaruhan antara adat-istiadat, hukum adat, hukum nasional, dan hukum agama. Pada tingkat nasional, dinamika ini dapat ditemukan pada pertarungan politik antara kubu yang ingin mengubah dan yang ingin mempertahankan status quo. Kami telah memaparkan hasil perdebatan selama lebih dari seratus tahun mengenai perkawinan anak. Sampai sekarang ini belum terdapat titik temu tentang umur minimal perkawinan. Hal ini karena masing-masing pemangku kepentingan mengacu pada sumber hukum yang berbeda untuk menentukan kapan seorang anak boleh menikah. Perbedaan mengenai umur dilatarbelakangi oleh perbedaan pemaknaan mengenai konsep anak itu sendiri.

Tetapi, pemahaman mengenai perubahan atau keberlangsungan status quo hanya dapat dipahami apabila peneliti menganalisa dinamika tersebut pada tingkat lokal/daerah. Dalam kasus perkawinan anak ternyata pengaruh tokoh agama lokal sangat besar dan juga pengaruh tokoh adat yang bahkan mencoba memperkuat kedudukannya pasca Reformasi. Penguatan identitas di daerah ikut mempengaruhi penegak hukum negara tingkat lokal yang kemudian memilih untuk berpihak pada tokoh agama dan adat. Mereka cenderung tidak menggubris peraturan hukum yang dikeluarkan pemerintah, apabila bertentangan dengan agama serta kebiasaan dan hukum adat lokal. Perilaku yang sama ditemukan di masyarakat setempat yang budaya hukumnya juga masih mengacu pada itu. Dalam rangka menggali adat istiadat dan hukum adat yang melatarbelakangi budaya hukum terkait hukum perkawinan, sumber yang dihasilkan para pakar hukum adat kolonial berlimpah. Sayangnya, peneliti hukum adat Indonesia jarang dapat memanfaatkannya karena hampir seluruh badan pustaka itu dalam Bahasa Belanda yang tidak mereka kuasai.

Kesimpulan lain adalah bahwa merevisi undang-undang atau menciptakan undang-undang baru, juga Perppu, tidak akan cukup untuk mengubah status quo. Legal reform memang dibutuhkan untuk menetapkan norma baru mengenai umur perkawinan minimum. Namun, strategi itu bisa menjadi bumerang apabila memicu perlawanan seperti terjadi pada masa lalu. Aturan teknis yang dikeluarkan Kementerian Hukum dan HAM untuk mempersulit perkawinan anak sebenarnya juga bisa berdampak positif. ${ }^{84}$ Misalnya perlu dijamin anak memiliki akte kelahiran yang sah. Bila tidak ada, harus diurus melalui penetapan dari pengadilan sesuai Pasal 55 UU Perkawinan sebelum perkawinan dapat dicatat. Akte kelahiran sebagai bukti legal identity akan membantu pencegahan pemalsuan 
umur. Law enforcement saat ini masih lemah di akar rumput. Pasal 20 UU Perkawinan memang mewajibkan petugas pencatatan perkawinan di KUA untuk mencegah perkawinan yang tidak memenuhi syarat, termasuk yang melanggar Pasal 7 (1) tentang umur perkawinan minimum. Namun bila petugas pencatatan perkawinan tidak melaksanakan kewajiban itu atau menghindarinya dengan cara lalai memverifikasi umur calon pengantin, dia tidak kena sanksi apapun. Sanksi hukum memang ada, tetapi aktor lokal sudah mengatur supaya syarat usia dipenuhi, dengan cara memalsukannya, yang menurut mereka demi kepentingan komunitas mereka sendiri. Tentu ada imbalan berupa pemberian sejumlah uang secara sukarela karena di tingkat lokal tidak ada petugas pembantu yang digaji. Dampaknya, petugas pencatatan perkawinan tidak merasa takut menghadapi sanksi resmi berdasarkan undang-undang.

Terakhir, perlu diantisipasi bahwa kasus kehamilan remaja di luar nikah tetap akan terjadi, karena kekurangan pendidikan mereka tentang kesehatan reproduktif, seangkan perilaku seksual remaja tetap akan sulit dicegah mengingat mobilitas mereka tinggi dan mereka mempunyai akses pada internet melalui telepon seluler. Ada dua terobosan di ruang lingkup hukum yang sedang diperdebatkan. Pertama, kriminalisasi pelaku perkawinan anak yang diusulkan dalam rancangan undang-undang perubahan KUHP. Tentu ini bukan solusi, apalagi bila umur perkawinan minimal untuk perempuan dinaikkan dari 16 menjadi 18 tahun, yang diusulkan beberapa pihak. Dampak yang dapat diantipasi adalah jumlah kasus perkawinan anak akan meningkat tajam. Terobosan kedua adalah menjamin implementasi dispensasi sebagaimana diatur dalam Pasal 7 (2) UU Perkawinan. Alternatif ini lebih menjamin kepastian hukum bagi status perkawinan dan status anak serta hak mereka jika bercerai atau pasangan meninggal. Kepastian ini juga membuka akses mereka pada serangkaian pelayanan dan fasilitas pemerintah (akte nikah, kartu Keluarga, Kartu Indonesia Sehat dan seterusnya). Dalam hal pemberian dispensasi, hak anak untuk menyetujui atau tidak menyetujui pernikahan (consent) juga penting untuk dijamin. Untuk itu hakim harus berupaya secara serius untuk menggali keinginan calon pengantin perempuan dan keinginan lakilaki dalam sesi terpisah, selanjutnya juga diadakan sesi terpisah dengan orang tua mereka. Lagipula dispensasi dari Pengadilan harus terjangkau dari segi biaya, dan didukung oleh informasi kepada masyarakat mengenai kewajiban dispensasi ketika pengantin belum cukup umur. Bila dilihat dari sudut kepentingan remaja perempuan (dan juga remaja laki-laki) alternatif kedua jauh lebih menguntungkan.

Justru karena peraturan formal yang dikeluarkan negara kemungkinan besar tidak akan afdol untuk menurunkan prevalensi perkawinan anak dengan sendiri, maka perlu disertai strategistrategi non-hukum, seperti yang digambarkan dalam kasus Toba Batak. Pertama, karena tokoh agama dan tokoh adat masih berperan besar dalam memfasilitasi perkawinan anak saat ini, mindset mereka perlu diubah melalui kegiatan yang menawarkan tafsiran agama Islam yang mendukung penghapusan perkawinan anak. Strategi itu telah diuji-coba beberapa LSM dan didukung oleh Fatwa KUPI (Kongres Ulama Perempuan Indonesia 27 April 2017). Strategi lain menyangkut perubahan perilaku remaja juga sudah diupayakan melalui program Kementerian Pendidikan dan Kesehatan, namun biasanya kurang menyentuh remaja di desa, sedangkan prevalensi perkawinan anak di sana justru lebih tinggi daripada di daerah perkotaan. Mendorong terwujudnya wajib pendidikan 12 tahun melalui pendirian lebih banyak sekolah SMA dan SMK di daerah perdesaan juga dapat membantu.

Isu hukum lain menyangkut hak anak. Yang paling ditakuti adalah sanksi sosial apabila remaja sudah hamil di luar nikah. Solusi yang biasa untuk menghindari aib keluarga diketahui adalah segera menikahkan anak perempuan yang sudah hamil. Perkawinannya pada umumnya diatur secepatnya oleh kedua keluarga dulu dengan bantuan tokoh agama dan perangkat desa. Anak perempuan atau lelaki sulit menentang orang tuanya atau kakek 
neneknya. Mereka didorong atau bahkan dapat dikatakan dipaksa untuk menikah. Itu juga bisa terjadi, ketika orang tua ingin mencegah zina saat anaknya yang sudah berpacaran. Kemanakah anakanak ini bisa pergi untuk memperoleh bantuan hukum agar hak untuk memutuskan sendiri nasib mereka tidak diabaikan? Secara de facto mereka tidak punya akses pada keadilan (access to justice). Mengintroduksi peraturan lebih ketat atau bahkan mengkriminalisasi hubungan seksual di luar nikah sama-sama merampas hak remaja untuk melakukan eksplorasi seksualitas mereka. Siapa yang mempunyai hak istimewa untuk menentukan perilaku para remaja? Ayah mereka, ibu mereka, orang tua angkat anak, kakak-kakak, guru, tetangga, pemimpin agama, perangkat desa? Ataukah remaja laki-laki dan perempuan sendiri?

Sejauh kami tahu, kegiatan yang dituju pada tokoh adat masih jarang diupayakan. ${ }^{85}$ Begitu pula peningkatan pengetahuan tentang hukum negara (legal literacy), melalui sosialisasi tentang pentingnya penghapusan perkawinan anak dan peraturan yang berlaku untuk mengubah sikap dan perilaku orang tua yang masih memilih mengawinkan anaknya pada usia belia. ${ }^{86}$ Sangat penting juga peningkatan legal literacy untuk anak remaja, baik perempuan dan lelaki. Mungkin itu bisa menjadi tugas dan topik penelitian pakar hukum adat bekerja sama dengan pihak terkait lain di masa yang akan datang.

\section{DAFTAR PUSTAKA}

\section{A. Buku}

Bemmelen, Sita van, 2018, Christianity, Colonization, and Gender Relations in North Sumatra. A Patrilineal Society in Flux, Brill, Leiden / Boston.

Blackburn, Susan, 2007, Kongres Perempuan

Pertama. Tinjauan Ulang, Yayasan Pustaka Obor Indonesia, Jakarta.

Eddyono, Supriadi Widodo, et al., 2016, Menyingkap Tabir Dispensasi Perkawinan: Analisis Terhadap Praktik Perkawinan Anak di Kab. Tuban, Kab. Bogor, dan Kab. Mamuju, Koalisi 18+, Jakarta.

Evenhuis, Mark \& Jeniffer Burn, 2014, Just Married, Just a Child: Child Marriage in the Indo-Pacific Region, Plan International Australia, Melbourn

Horii, Hoko, 2015, Uncovering Difficulties in the Implementation of International Human Rights Laws in the Indonesian Pluralistic
Legal System: Issue of Child Marriage in West Java, Master Thesis, Nagoya University, Nagoya.

Irianto, Sulistyowati, 2003, Perempuan di Antara Berbagai Pilihan Hukum, Yayasan Pustaka Obor Indonesia, Jakarta.

Kartikasari, Dian, 2016, Kearah Реrppu Anti Perkawinan Anak, Tim KPPA, Jakarta.

Locher-Scholten, Elsbeth, 2000, Women and the Colonial State: Essays on Gender and Modernity in the Netherlands-Indies 1900-1942, Amsterdam University Press, Amsterdam.

Mampu, 2015, Kehamilan - sebuah Anugerah?

Kompilasi Laporan Penelitian Kehamilan Tidak Diinginkan/KTD di Delapan Propinsi - Pulau Sumatera, Project Report, Program Mampu, Jakarta.

Soebadio, Maria Ulfah, Perjuangan untuk mencapai Undang-Undang Perkawinan: Ceramah,

85 Rumah KitaB menjalankan kajian Qawamah Walayah, dan sudah mempublikasi beberapa buku seperti 'Maqashid al Islam: Konsep Perlindungan Manusia dalam Perspektif Islam'.

86 Plan International, bersama RutgersWPF dan Aliansi Remaja Independen (ARI) bekerja dengan pendekatan serupa. Mereka mengacu pada ini sebagai "pendekatan dua jalur", yang berarti bahwa tujuan proyek bukan hanya untuk memberdayakan para gadis, tetapi juga bekerja untuk mengubah pola pikir orang-orang di sekitar para gadis. Lihat Nadira Irdiana, "GIRLS 2030”, Presentasi, Workshop on Child Marriage in Indonesia: Research Sharing and Academic Writing, Universitas Indonesia, Jakarta, 27-29 April 2017. 
tanggal 28 Februari 1981 di Gedung

Kebangkitan Nasional Jakarta, Yayasan Idayu, Jakarta.

Soekanto, Soerjono, 1979, Masalah Kedudukan dan Peranan Hukum Adat, Penerbit Academica, Jakarta.

Soekanto, Soerjono, 1982, Kedudukan Dan Peranan Hukum Adat Di Indonesia, Penerbit Kurnia Esa, Jakarta.

Soepomo, Raden, 1967, Hukum Perdata Adat Djawa Barat. Diterjemahkan oleh Nj. Nani Soewondo SH (dari Het adatprivaatrecht van West-Java, 1933), Djambatan, Djakarta.

Sonius, Harko, "Introduction", dalam Holleman, Johan Frederik, 1981, Van Vollenhoven on Indonesian Adat Law, Martinus Nijhoff, The Hague.

Wignjodipuro, Surojo, 1982, Kedudukan serta Perekembangan Hukum Data Setelah Kemerdekaan, PT Gunung Agung, Jakarta.

Wilken, George Alexander, \& Ossenbruggen, Frederik Daniel Eduard van, 1912, De Verspreide Geschriften van Prof. Dr. G.A. Wilken, Van Dorp, Semar

\section{B. Artikel Jurnal}

Bedner, Adriaan \& Huis, Stijn van, "Plurality of Marriage Law and Marriage Registration for Muslims in Indonesia: A Plea for Pragmatism", Utrecht Law Review, Vol. 6, No. 2, Juni 2010.

Blackburn, Susan \& Bessell Sharon, "Marriageable Age: Political Debate on Early Marriage in Twentieth-Century Indonesia", Indonesia, No. 63, 1997.

Buttenheim, Alison \& Nobles, Jenna, "Ethnic Diversity, Traditional Norms, and Marriage Behaviour in Indonesia", Population Studies, Vol. 63, No. 3, 2009.

BPS, 2016, Kemajuan yang Tertunda: Analisis Data Perkawinan Usia Anak di Indonesia, Badan Pusat Statistik, Jakarta.

Candraningrum, Dewi, et al., "Takut Akan Zina, Pendidikan Rendah, dan Kemiskinan: Status Anak Perempuan dalam Pernikahan Anak di
Sukabumi Jawa Barat", Jurnal Perempuan 88, Vol. 21, No.1, Februari 2016.

Grijns, Mies, et al., "Pernikahan Anak Di Sukabumi Jawa Barat: Diri Dan Agensi Anak Perempuan (English translation expected end 2018 as Child Marriage in Sukabumi West Java: Self and Agency of Girls)", Jurnal Perempuan 88, Vol. 21, No.1, Februari 2016.

Grijns, Mies \& Horii, Hoko, "Child Marriage in a Village in West Java (Indonesia): Compromises between Legal Obligations and Religious Concerns", Asian Journal of Law and Society, 2018.

Helbig, Karl, "Einige Bemerkungen über die Sittlichen Zustãnde und die Erotik der TobaBatak auf Sumatra", Baesler Archiv, Vol.18, 1935.

Jones, Gavin, "Which Indonesian Women Marry Youngest, and Why?" Journal of Southeast Asian Studies, Vol. 32, No. 1, Februari 20

\section{Disertasi}

Boomgaard, Sipko Ritzo, 1926, De Rechtstoestand van de Getrouwde Vrouw volgens het Adatrecht van Nederl.-Indië, Disertasi, Rijksuniversiteit te Leiden, Leiden.

Huis, Stijn Cornelis van, 2015, Islamic Courts and Women's Divorce Rights in Indonesia: The Cases of Cianjur and Bulukumba, Disertasi, Leiden University, Leiden.

Vel, Jacqueline, 1994, The Uma-Economy: Indigenous Economics and Development Work in Lawonda, Sumba (EasternIndonesia), Disertasi, Wageningen University, Wageningen.

\section{Makalah}

Bedner, Adriaan, "Some Notes on The Future of Indonesian Legal Education", Makalah, International Conference on Southeast Asia Legal Education: Preparing Lawyers for Tomorrow's Society and Profession, Fakultas Hukum Universitas Airlangga, Surabaya, 2 Oktober 2013.

BPS, "Perkawinan Usia Anak di Indonesia (Kajian dari Data Susenas BPS)", Presentasi oleh 
Gantjang, Direktorat Statistik Kesejahteraan Rakyat, dalam Dialog Publik "Data Berbasis Gender dan Inklusif", Institut KAPAL Perempuan, Jakarta, 24 September 2018.

Irdiana, Nadira, “GIRLS 2030”, Presentasi, Workshop on Child Marriage in Indonesia: Research Sharing and Academic Writing, Universitas Indonesia, Jakarta, 27-29 April 2017.

Irianto, Sulistyowati, "Adat Law in Legal Pluralism Perspective: Inheritance Dispute Case and Gender Justice", Makalah, Conference Adat Law 100 Years On: Towards a New Interpretation? Van Vollenhoven Institute, Leiden University, Leiden, 22-24 Mei 2017.

Munte, Alfonso, 2017, "Pernikahan Anak: Studi Kasus antara Nikah Adat dan Nikah Rehap (Gereja), Dayak Kebahan, Kayan Hulu, Kalimantan Barat", Makalah, Workshop on Child Marriage in Indonesia: Research Sharing and Academic Writing, Universitas Indonessia, Jakarta, 27 April 2017.

\section{E. Antologi}

Bemmelen, Sita van \& Grijns, Mies, "Perdebatan Tentang Perkawinan Anak, Mulai dari Zaman Kolonial Hingga ke Kurun Jawa Masa Kini: Adat, Agama dan Negara", dalam Grijns, Mies, et al., 2018, Menikah Muda di Indonesia: Suara, Hukum dan Praktik, Yayasan Pustaka Obor Indonesia, Jakarta.

Robinson, Kathryn, "Muslim Women's Political Struggle for Marriage Law Reform in Contemporary Indonesia", dalam Whiting, Amanda \& Evans, Carolyn, 2006, Mixed Blessings. Laws, Religions, and Women's Rights in the Asia-Pacific region, Martinus Nijhoff Publishers, Leiden.

Sukmayeti, Evi, "Bingkai Merariq Menurut Awig-Awig dan Praktik Perkawinan Anak dalam Masyarakat Sasak Labuapi" dalam Grijns, Mies, et al., 2018, Menikah Muda di Indonesia: Suara, Hukum dan Praktik, Yayasan Pustaka Obor Indonesia, Jakarta.

\section{F. Internet}

Editor Almanhaj, "Hamil di Luar Nikah dan Masalah Nasab Anak Zina", https:// almanhaj.or.id/2099-hamil-di-luar-nikahdan-masalah-nasab-anak-zina.html, diakses tanggal 5 Agustus 2018.

Editor Almanhaj, "Status Anak Zina", https:// almanhaj.or.id/3354-status-anak-zina.html, diakses tanggal 5 Agustus 2018.

Eva Mazrieva, "Jokowi Setuju Dorong Pengesahan Perppu Pencegahan Perkawinan Anak", https://www.voaindonesia.com/a/jokowisetuju-dorong-pengesahan-perppupencegahan-perkawinan-anak/4358431. html, diakses tanggal 23 April 2018.

Farid, Yuniman, "MK Beri Status Hukum Anak Luar Nikah", www.dw.com/id/mk-beristatus-hukum-anak-luar-nikah/a-15747844, diakses tanggal 5 Agustus 2018.

Ramadhani Nurul F. \& Ati Nurbaiti, "Avoiding child marriage "mandatory", http://www. thejakartapost.com/news/2017/04/28/ avoiding-child-marriage-mandatory.htmli, diakses tanggal 29 April 2017.

Susetyo, Hero, "Pernikahan di Bawah Umur: Tantangan Legislasi dan Harmonisasi Hukum", https://search.hukumonline.com/ $i d /$ search/browse? $q=H e r u+$ Susetyo, diakses 4 Desember 2014.

Vel, Jacqueline \& Muur, Willem van der, 2017, Adat Law 100 Years On: Towards a New Interpretation? Report of the International Adat Conference 22-24 May 2017, http:// www.kitlv.nl/conference-adat-law-100-year/, Van Vollenhoven Institute, Leiden University, Leiden.

YPHA, 2015, "Pernyataan Sikap Koalisi 18+ Atas Keputusan MK", http://www.ypha.or.id/ $w e b / ? p=1608$, diakses 4 Februari 2017

\section{G. Peraturan Perundang-undangan}

Staatsblad 1931 Nomor 54

Kitab Undang-Undang Hukum Pidana

Kompilasi Hukum Islam 
Undang-Undang Nomor 1 Tahun 1974 tentang Perkawinan (Lembaran Negara Republik Indonesia Tahun 1974 Nomor 1, Tambahan Lembaran Negara Republik Indonesia Nomor 3019).

Undang-Undang Nomor 23 Tahun 2002 tentang Perlindungan Anak (Lembaran Negara Republik Indonesia Tahun 2002 Nomor 109, Tambahan Lembaran Negara Republik Indonesia Nomor 4235).

\section{H. Putusan Pengadilan}

Putusan Mahkamah Konstitusi Nomor 30-74/ PUUXII/2014 perihal Pengujian Undang-Undang Nomor 1 Tahun 1974 tentang Perkawinan terhadap Undang-Undang Dasar Negara Republik Indonesia Tahun 1945, 18 Juni 2015.
Putusan Mahkamah Konstitusi Nomor 22/PUUXV/2017 Perihal Pengjian Undang-Undang Nomor 1 Tahun 1974 tentang Perkawinan terhadap Undang-Undang Dasar Negara Republik Indonesia Tahun 1945, 13 Desember 2018.

\section{Dokumen Lain}

Onderzoek naar de Mindere Welvaart der Inlandsche Bevolking op Java en Madoera:

1914, IXb3 Verheffing van de Inlandsche Vrouw, Drukkerij Papyrus, Batavia.

1911, IXd Adatregelingen in de Inlandsche Kristengemeenten op Java, Drukkerij G. Kolff \& Co., Batavia.

1914, Xb Deel II, De volkswelvaart op Java en Madoera, Drukkerij Ruygrok \& Co., Batavia. 